\title{
How Does Labor Market Size Affect Firm Capital Structure? Evidence from Large Plant Openings*
}

\author{
by
}

\author{
Hyunseob Kim $\dagger$ \\ Cornell University
}

CES 15-38

November, 2015

The research program of the Center for Economic Studies (CES) produces a wide range of economic analyses to improve the statistical programs of the U.S. Census Bureau. Many of these analyses take the form of CES research papers. The papers have not undergone the review accorded Census Bureau publications and no endorsement should be inferred. Any opinions and conclusions expressed herein are those of the author(s) and do not necessarily represent the views of the U.S. Census Bureau. All results have been reviewed to ensure that no confidential information is disclosed. Republication in whole or part must be cleared with the authors.

To obtain information about the series, see www.census.gov/ces or contact Fariha Kamal, Editor, Discussion Papers, U.S. Census Bureau, Center for Economic Studies 2K132B, 4600 Silver Hill Road, Washington, DC 20233, CES.Papers.List@census.gov. To subscribe to the series, please click here. 


\begin{abstract}
I examine how the labor market in which firms operate affects their capital structure decisions. Using the US Census Bureau data, I exploit a large plant opening as an abrupt increase in the size of a local labor market. I find that a new plant opening leads to a $2.6 \%$ to $3.9 \%$ increase in the debt-to-capital ratio of existing firms in the "winner" county relative to the "runner-up" choice. This result is consistent with larger labor markets making a job loss less costly, which in turn reduces indirect costs of financial distress. Moreover, this spillover effect is larger for firms 1) that have a larger fraction of employees in the affected county, 2) that employ the same type of workers as the new plant, and 3) that have larger unexploited benefits of debt.
\end{abstract}

\footnotetext{
* This paper is based on my PhD dissertation at Duke University. I am indebted to my committee members, Peter Arcidiacono, Alon Brav, John Graham (Chair), Manju Puri, and S. Viswanathan. I appreciate helpful comments from Ashwini Agrawal (discussant), Nittai Bergman, Murillo Campello, Felix Feng, Andrew Karolyi, Rick Mansfield, David Matsa, Roni Michaely, Holger Mueller, Howard Kung, Justin Murfin, Armin Rick, Michael Waldman, and seminar and conference participants at Cornell, Duke (Economics and Fuqua), LBS, McGill, Rice, SMU, Houston, UIUC, UNC-Chapel Hill, TRDC Conference, and WFA Meeting. I thank Bert Grider at the TRDC for helping with data and clearance requests, Evan Buntrock at the NYRDC (Cornell) for administrative assistance, and Alan Kwan and Cindy Lu for research assistance. Any opinions and conclusions expressed herein are those of the author and do notnecessarily represent theviews of the US Census Bureau. All results have been reviewed to ensure that no confidential information is disclosed. This research uses data fromthe Census Bureau's Longitudinal Employer Household Dynamics Program, which was partially supported by the following National Science Foundation Grants SES-9978093, SES-0339191 and ITR-0427889; National Institute on Aging Grant AG018854; and grants from the Alfred P. Sloan Foundation. I acknowledge financial support from the Kwanjeong Educational Foundation. All errors are my own. † Johnson Graduate School of Management, Cornell University; Email: hk722@cornell.edu.
} 


\section{Introduction}

Existing research has documented significant and persistent differences in worker outcomes across geographic areas (e.g., counties and metropolitan areas) of different "sizes." For example, workers in larger labor markets are more productive (Greenstone, Hornbeck, and Moretti, 2010), earn higher wages (Glaeser and Maré, 2001), and produce more innovative output (Moretti, 2011) than similar workers in smaller areas. ${ }^{1}$ However, much less is known about how labor markets affect firms' outcomes, particularly their financial policies.

A key advantage of a large local labor market is that it facilitates workers to reallocate across firms (e.g., Petrongolo and Pissarides, 2006). When reallocation across jobs is easier, workers require a smaller wage premium to firms for their job loss risk (Abowd and Ashenfelter, 1981; Acemoglu, 1997). Thus, when firms choose "riskier" policies such as taking on more debt, large labor markets reduce marginal compensating differentials for increased layoff risk (Sharpe, 1994). Given this reduced cost of using financial leverage in a larger market, firms operating in such a market would use higher leverage, other things held constant. In this paper, I seek to provide evidence on this link between the size of labor markets and capital structure.

To test this prediction, I use an empirical setting in which the local labor market for manufacturing workers expands abruptly due to a large manufacturing plant opening in a county. In the US, dozens of locations typically bid to "win" a new plant. ${ }^{2}$ Because firms ultimately choose among locations that would maximize their profits, counties at the final stage of the selection process tend to be comparable in their economic characteristics. Thus, I hand collect data on the counties that were ultimately successful in attracting new manufacturing plants ("winners") and on the counties that were the new plants' runner-up choices ("runners-up"). Figure 1 shows the (approximate) location of these winner and runner-up counties. Prior to a plant opening, the winner and runner-up counties are statistically equivalent in terms of the number of manufacturing plants, average employment

\footnotetext{
${ }^{1}$ Large labor markets are often referred to as 'thick markets' (e.g., Moretti, 2011). I use 'large labor market' for consistency.

2 The case of Tesla Motors illustrates this competition among localities in the US to attract large plants. See "Tesla Confirms Nevada to Get Battery Factory," The Wall Street Journal, 09/04/2014. The article reports that sites in Arizona, California, Nevada, New Mexico, and Texas were competing for the new plant before a Nevada site near Reno was finally chosen. It quotes Tesla CEO Elon Musk's comment that the decision between Nevada and the other states was 'tight.'
} 
and output per plant, and output growth rate. Combining this information on new plants with plant-level operating data from the US Census Bureau, I identify existing plants located in the winner and runner-up counties and the parent firms that own these plants. Using existing firms in the runner-up counties as a counterfactual for existing firms in the winner counties, I search for a link between labor market size and corporate capital structure.

This empirical setting is well suited to test the link in the following ways. First, firms in the runner-up counties appear to be a valid counterfactual of firms in the winner counties. These counties are the two or three final candidates that have survived a competitive site selection process involving dozens of initial candidates. Hence, it is reasonable to assume that both counties satisfy key criteria for a new plant's site, such as transportation infrastructure and proximity to suppliers. In addition, prior to the plant opening, observable firm and plant characteristics including size, profitability, and growth rates are statistically equivalent in the winner and runner-up counties. Importantly, firms in these counties show statistically equivalent trends in leverage ratios for a few years before the plant opening, validating the parallel trend assumption. My research design builds upon work by Greenstone and Moretti (2004) and Greenstone, Hornbeck, and Moretti (2010)-henceforth GHM — demonstrating that the winner and runner-up counties, as well as plants therein, are highly comparable.

Second, given that geographic mobility has significant economic and psychological costs (Sjaastad, 1962), the relevant labor market for workers is likely local. Hence, I exploit variation in labor market size at the county level. ${ }^{3}$ Third, previous research suggests that labor market size is likely important for manufacturing workers' job search because reallocation across jobs is particularly costly for workers with manufacturing skills (e.g., Jacobson et al., 1993; Couch and Placzek, 2010). Lastly, manufacturing industries largely produce nationally traded goods, which makes alternative channels related to local product market competition less of a concern.

I first show that the average new manufacturing plant accounts for $27 \%$ of the total manufacturing employment in the winner county (a proxy for labor market size) measured one year prior to the opening, using a sample of large manufacturing plant openings from

\footnotetext{
${ }^{3}$ Section 6.6 examines the effect of plant openings on firms in the same Metropolitan Statistical Area (MSA).
} 
1980 to 1995. This magnitude implies a significant expansion of the local market for manufacturing labor. Within a year after the plant opening, there is a 2.2 percentage point increase in the debt-to-capital ratio for parent firms in manufacturing industries that operate plants in the winner counties. In contrast, the leverage ratios for manufacturing firms operating plants in the runner-up counties remain flat during the same period, controlling for firm and year fixed effects and key determinants of leverage. Four years after the plant opening, leverage increases by 3.9 percentage points for the firms in the winner county relative to those in the runner-up county. Leverage increases more for firms that have more significant workforce in the affected counties. ${ }^{4}$

In addition, I provide new evidence that displaced workers experience a smaller wage loss in larger local labor markets using data from the US Census Bureau's Longitudinal Employment and Household Dynamics (LEHD) program. Moreover, I find that the displaced workers tend to stay in the same industry after a job loss in a large market. These findings are consistent with the argument that a large market mitigates a wage loss by reducing the loss of (industry-) specific human capital (Couch and Placzek, 2010; Tate and Yang, 2015a), verifying a key assumption of my research design.

Further analysis suggests that an expansion of the local market for manufacturing labor drives the leverage increase, as opposed to, for example, an increase in population or a local-level shock. First, the opening of a manufacturing plant has virtually no impact on the capital structure of non-manufacturing firms (e.g., retail, transportation) in the same county. Similarly, opening large non-manufacturing establishments (e.g., warehouses, call centers) has no significant effect on the leverage of existing manufacturing firms. Second, within manufacturing, the effect of plant openings is more pronounced for firms operating in the same two-digit SIC industry as the new plant, which are likely to employ the same type of workers. Third, the plant opening has a significant effect on the leverage of firms only in industries sharing the same type of labor as the new plant (measured by flow of workers between existing and new plants' industries). The collection of evidence is consistent with

\footnotetext{
${ }^{4}$ On average, plants in the winner county account for $25 \%$ of the total workforce of the parent firms in the sample.
} 
the prediction that a plant opening leads to an increase in leverage to the extent that existing firms' relevant labor market expands due to the new plant.

A trade-off model of capital structure predicts that when a large labor market reduces the cost of financial distress, firms increase leverage (see Section 2). Importantly, this effect is stronger when the marginal benefit of debt is larger. Consistent with this prediction, I find that the increase in leverage is pronounced when the existing firms have larger unexploited tax benefits of debt (Graham, 2000).

Theories of local labor markets suggest that the effect of labor market size on wages may be unclear a priori. On the one hand, workers would require smaller compensating differentials for wage loss risk in a larger market (e.g., Moretti, 2011). On the other hand, a larger market could incentivize workers to invest in skills and be more productive (Rotemberg and Saloner, 2000) which pushes up wages. In addition, when a labor market becomes larger, firms increase leverage which in turn increases wages as well (see Section 2). Accordingly, I find that wages remain flat while labor productivity increases by $3.1 \%$ after a plant opening in the winner vs. runner-up counties.

Lastly, I examine the external validity of the main results based on plant openings by using a large panel of firms in Compustat matched with plants in the Census data from 1977 to 2010 (see Online Appendix A). Consistent with the earlier result, I find that a one standard deviation increase in labor market size is associated with a 1.4 percentage point increase in corporate leverage after controlling for firm and year fixed effects and the firmlevel determinants of capital structure.

This paper contributes to the strands of literature on links between the labor market, firm policies (see Pagano and Volpin (2008) for an overview), ${ }^{5}$ and agglomeration economies (see e.g., Duranton and Puga (2004) for a review). ${ }^{6}$ First, I show that labor market size, by affecting workers' ability to move across jobs, drives corporate capital structure decisions. This finding adds to the literature on human capital risk and firm capital structure. For example, Agrawal and Matsa (2013) argue that state-level unemployment insurance benefits affect firm capital structure because they mitigate workers' earnings loss in unemployment.

${ }^{5}$ A related line of research examines the strategic role of debt in bargaining with unionized labor (e.g., Bronars and Deere, 1991; Matsa, 2010; Benmelech, Bergman, and Enriquez, 2012).

${ }^{6}$ See Davis, Fisher, and Whited (2014) for aggregate implications of agglomeration economies. 
Second, this paper provides novel evidence for spillover effects of agglomeration on capital structure at a geographical level. This finding identifies increased debt usage as an important benefit of firm clustering, which implies that firms operating in a large local labor market (e.g., Atlanta, GA) use more debt in response to lower costs of financial distress than otherwise similar firms located in a smaller market (e.g., Knoxville, TN). Third, this paper provides new evidence that large labor markets mitigate wage losses after a job displacement. This finding verifies a key channel through which larger labor markets lead to an increase in financial leverage - namely, lower costs of financial distress in the form of wage premia for job loss risk. Lastly, the increased labor productivity after a local labor market expansion is consistent with theories of agglomeration arguing that workers invest more in specific skills when they become more usable in the local market (Acemoglu, 1997; Rotemberg and Saloner, 2000), providing evidence for a potential mechanism of the effects I find.

\section{Simple Model of Labor Market Size and Capital Structure}

In this section, I illustrate conceptual links between the size of labor markets and corporate leverage policy using a simple static trade-off model of capital structure with labor as a production input. The framework for production is adapted from Acemoglu (1997) and that for capital structure is from Titman (1984) and Berk, Stanton, and Zechner (2010). Let $L$ be a firm's leverage ratio, which is defined as the ratio of debt to the sum of equity and debt. Suppose that $L[0,1]$ generates a tax benefit $T(L)$, which is an increasing, concave function of $L$ (Graham, 2000). L also increases the expected costs of financial distress, $p(L) \cdot C_{F},{ }^{7}$ where $p(L)$ is the probability of financial distress and is an increasing, convex function of $L$.

The firm hires labor (in size 1) to produce output by paying the wage $W$, and the labor invests in required skills for which the cost to the worker (e.g., effort) is $K$. For simplicity, I assume that investments in skills have a positive present value to the worker, $S$, beyond the current period if she i) stays within the current firm or ii) moves to a firm that uses the same skills, but zero value at all other firms. Importantly, I assume that the worker

\footnotetext{
${ }^{7} C_{F}$ includes "traditional" costs of financial distress such as those due to bankruptcy process, loss of market share, and asset fire sales (see Almeida and Philippon (2007)). However, $C_{F}$ does not include the cost of distress due to labor market frictions which I introduce later.
} 
faces search frictions in the local labor market (Diamond, 1982). As a result, if the worker is laid off from the current firm, she is not able to find another job using her skills with probability $u(<1)$. For simplicity, I assume that if a firm becomes financially distressed (with a probability $p(L))$, the worker is laid off with a probability one. ${ }^{8}$

The firm solves the following maximization problem by choosing the optimal level of leverage $L^{\text {? }}$ :

$\max _{L} T(L)-p(L) \cdot C_{F}-W$

s.t. $W+[1-p(L) \cdot u] \cdot S \geq K$.

Equation (2) represents the worker's participation constraint (PC) condition: The wage $W$ (assumed to be paid up-front for simplicity) must exceed the cost of effort $K$ net of the future expected benefits from investing in skills. Therefore, the firm offers the following take-it-or-leave-it wage offer to the worker, who would accept it:

$W=K-[1-p(L) \cdot u] \cdot S$.

To derive the firm's optimal leverage choice, substituting $W$ in equation (3) into equation (1) and taking the derivative of the equation w.r.t. $L$ gives the following first-order condition:

$T^{\prime}(L)=p^{\prime}(L) \cdot\left(\mathrm{u} \cdot \mathrm{S}+\mathrm{C}_{F}\right)$.

Given that $\not($.$) is increasing, convex and T($.$) is concave, the optimal leverage ratio is$ decreasing in $u$ and $C_{F}$. Therefore, an increase in labor market size (i.e., smaller $u$ ) would lead to an increase in the optimal leverage ratio, $L^{*}$. (Main Prediction) ${ }^{10}$ In addition, equation (3) shows three determinants of wages, $W$. First, $K$ represents compensation for the worker's effort to acquire skills (or human capital). Second, $p(L) \cdot u \cdot S$ captures compensating differentials for the risk of job loss conditional on financial distress of the firm (Abowd and Ashenfelter, 1981; Berk et al., 2010). Third, $-S$ represents the present value of compensation

8 A similar result will be obtained if I assume a probability of a job loss conditional on financial distress that is less than one. See Agrawal and Matsa (2013) and Graham et al. (2015) for evidence that employees of distressed firms face a significant risk of job loss.

${ }^{9} \mathrm{I}$ assume that the firm produces a fixed amount of output given the worker's skill investment $K$. Thus, the firm's objective function does not include the value of output.

${ }^{10} \mathrm{An}$ implicit assumption of this and other predictions of the model is that employees can perceive the effect of the firm's financial distress on their job security. See Brown and Matsa (2015) for recent evidence that job seekers accurately perceive the financial strength of potential employers and reduce their labor supply to firms experiencing financial difficulties. 
beyond the current period. Hence, a reduction in labor search costs $(u)$ would decrease the compensating differentials, and in turn the equilibrium wages $W$, other things held constant. However, given the result above that a decrease in $u$ leads to an increase in $L$, the net impact of reduced search costs on wages is ambiguous (Wage Prediction).

\section{Empirical Approach: A Quasi-natural Experiment}

I use the opening of a large manufacturing plant in a given county as an abrupt expansion of the local labor market in the sector. ${ }^{11}$ This increase in labor market size reduces the cost of financial distress stemming from frictions for workers to find a similar employer which, all else equal, leads the existing firms in the county to increase debt usage. One difficulty with this empirical approach is that plant opening decisions are driven by economic forces, and thus could be endogenous. For example, the economy of a county that ultimately attracts a large plant might have been growing faster than that of another county. Then, it is possible that the incumbent firms in the winner county have larger debt capacity and thus can increase leverage due to fast economic growth or increased supply of credit even in the absence of the new plant.

To avoid these endogeneity concerns, I hand-collect rankings of potential large manufacturing plant sites from the corporate real estate journal Site Selection. ${ }^{12}$ The "Million Dollar Plants (MDP) ${ }^{13}$ section provides information on the site selection process for notable, large plants, including the identity and characteristics of the new plant and the localities that were under consideration. Importantly, the MDP articles provide the identity of both i) the county that was ultimately successful in attracting the new plant (the "winner"), and ii) the county that was one of the final candidates but narrowly lost the competition (the "runnerup"). Using firms in the runner-up county as a counterfactual of those in the winner county in the absence of the new plant, I search for an empirical link between labor market size and capital structure.

\footnotetext{
11 The size of a labor market depends not just on the overall number of firms and workers but crucially on the skills of the workers. For example, a chemical engineer and an accountant in an identical city may face very different labor markets.

12 The title of the journal varies from 'Site Selection,' 'Industrial Development,' to 'Site Selection \& Industrial Development' depending on the year of publication. I refer to 'Site Selection' for consistency.

${ }^{13}$ The title of the section varies from 'Million Dollar Plants,' 'Million Dollar Facilities,' 'Location Reports,' to 'Top Deals.' I refer to 'Million Dollar Plants' for consistency.
} 
Previous research by Greenstone and Moretti (2004) and GHM (2010) provides evidence that the winner and runner-up counties as well as plants therein are comparable, validating the winner vs. runner-up comparison. While using a similar dataset of large plant opening events, these two papers examine the "agglomeration spillover effects" on real outcomes for existing plants and local economies, including total factor productivity (TFP), wages, and property values. My paper complements these papers by showing that a plant opening in a local market has an important impact on firm-level financial decisions, particularly capital structure.

There are important advantages of using information on the winner and runner-up counties of the plant opening cases to identify a valid counterfactual. First, the winner and runner-up counties have survived a site-selection process which usually involves dozens of initial candidates across the US and can take as long as several years. And the runner-up is one of the two or three final candidates that survived this process. Thus, it is plausible to assume that the runner-up lost only by a narrow margin, which is a key identifying assumption for my research design. ${ }^{14}$ Hence, it is reasonable to argue that both counties satisfy most of the important specifications for the new site, such as availability of labor forces, transportation infrastructure, and quality of life for employees, all of which are generally unobservable to the econometrician (GHM, 2010). In addition, firms and plants in the winner and runner-up counties were statistically indistinguishable before the plant opening in observable characteristics, including plant output, its growth rate, and determinants of capital structure, further validating the comparison.

Importantly, my analysis focuses on the manufacturing sector for the following reasons. First, past research shows that industry- or sector-specific human capital is more important for manufacturing than non-manufacturing workers. For example, Jacobson et al. (1993) and Couch and Placzek (2010) show that workers who were displaced from a manufacturing industry and subsequently found a job in a non-manufacturing industry experience a significantly larger wage loss relative to other displaced workers who move

\footnotetext{
${ }^{14}$ Quotes from the Million Dollar Plants articles illustrating this assumption include: "We found the three locations equally suitable." (TRW); "Yamaha officials stressed that any of the four final areas under consideration would have been an excellent location for their new facility." (Yamaha Motors); and "Jacksonville [a runner-up] was certainly a prime candidate for the center. We just had to choose between two excellent candidates" (MCI Communications).
} 
from non-manufacturing to manufacturing. Therefore, it is likely that a plant opening will lead to greater variation in the cost of job loss in the manufacturing sector. Moreover, the evidence suggests that labor markets are likely segmented between manufacturing and nonmanufacturing, and thus the introduction of a new employer in the manufacturing sector may not have a significant impact on job search costs for non-manufacturing workers. Therefore, I only study other manufacturing firms' capital structure changes in response to the opening of a manufacturing plant. Second, given that the manufacturing industries largely produce nationally (as opposed to locally) traded goods (Glaeser and Kohlhase, 2004), I am able to avoid alternative explanations related to local product market competition.

\section{Data and Descriptive Statistics}

\subsection{Data Sources and Sample Construction}

I hand-collect data on the opening of large manufacturing plants from the Million Dollar Plants (MDP) articles from 1980 to $1995^{15}$ and when relevant information is not available, I supplement the data with information from Greenstone and Moretti (2004). The MDP articles provide information on the location (i.e., city, county) that the firm ultimately chose for the new plant site and usually one or two runner-up locations that the firm had considered as potential sites in the US. In my main analysis, I focus on the impact of the plant opening on other existing firms in the same county and examine the robustness of results for the existing firms in the same Metropolitan Statistical Area (MSA) in Section 6.6.

I first match each new manufacturing plant from Site Selection with a plant in the Census Bureau's Standard Statistical Establishment List (SSEL) and Longitudinal Business Database (LBD) using the parent company name, state, county, opening year, and industry. ${ }^{16}$ If a new plant is not matched to a plant in the SSEL or LBD, I drop the case from the

${ }^{15}$ Greenstone and Moretti (2004) and GHM (2010) use similar sample periods, namely 1982-1993 and 19811993, respectively.

${ }^{16}$ The plant opening year is recorded as the earliest of the year of publication in Site Selection and the year in which the matched new plant appears in the SSEL or LBD for the first time (GHM, 2010). The locations are mostly recorded at the city level in Site Selection. Given that plant location is available only at the county level in the SSEL and LBD, I convert cities into counties. 
sample. ${ }^{17}$ Second, I identify all establishments in the winner and runner-up counties that are owned by firms other than the firm opening the new plant by using location information in the two Census databases. Third, I match these existing plants to parent firms in Compustat using a bridge file created by the Census Bureau. I obtain firm-level variables for leverage and financial controls from Compustat, focusing on manufacturing industries (SIC code 2000-3999). My identification strategy relies on the within-event comparability of the winner and runner-up firms but applying the matching procedure often leads to highly unbalanced numbers of firms between the counties for some events. To avoid potential biases in the estimate, I drop a plant opening event if the ratio of the selected firms in the winner county to those in the winner or runner-up counties is too small or too large: less than 0.05 or larger than $0.95 .^{18}$

This sample selection procedure yields 40 manufacturing plant opening cases from 1980 to 1995 , similar to prior research $(\mathrm{GHM}, 2010) \cdot{ }^{19} \mathrm{I}$ define the treatment window as four years before and after a plant opening for each event. I require parent firms in the sample to have at least 3\% of their employees located either in the winner or runner-up counties. ${ }^{20}$ Finally, I require each firm-year in the sample to have key control variables used in the analysis, including book assets, tangibility, market-to-book, and return on assets, all of which are lagged by one year relative to leverage. This selection procedure yields a sample of 5,872 firm-year observations. To facilitate the estimation of controls (e.g., year-fixed effects and firm-level controls), I add 46,083 firm-years from Compustat that are not affected by those events, producing the final sample of 51,955 firm-year observations from 1975 to 2000.

In addition, I obtain data on plant observations from the Census of Manufacturers $(\mathrm{CMF})$ and the Annual Survey of Manufacturers (ASM) maintained by the Census Bureau. ${ }^{21}$

\footnotetext{
17 The SSEL contains the Census Bureau's most complete data for business establishments in the US and the LBD tracks more than five million manufacturing and non-manufacturing establishments every year, essentially covering the entire US economy.

18 This issue arises essentially due to the limited number of public firms that have plants in some of the counties.

19 I match the events to Compustat data in addition to the Census plant-level datasets while GHM (2010) match to the Census datasets only.

20 Section 5.1 examines whether the impact of a plant opening is stronger for firms with a larger fraction of employees in the winner or runner-up counties.

21 The CMF covers all manufacturing plants in the US with at least one employee for years ending ' 2 ' or ' 7 ' (the "Census years"), including approximately 300,000 plants in each census. The ASM covers about 50,000 plants
} 
Both datasets provide information on the operation of plants including total value of shipments, labor hours, and wage bills, which I use to estimate the impact of a plant opening on wages and labor productivity. I also use the employer-employee matched data from the Census Bureau's LEHD program to examine the implications of local labor market size for the magnitude of displaced workers' wage loss. The LEHD datasets are based on the unemployment insurance (UI) records and track individual workers across firms over time covering about $96 \%$ of private sector employment in 30 states. They provide information on wages, employers, locations, and industries for each employment relation and on individual characteristics such as age and sex from 1985 to 2008. I winsorize all potentially unbounded variables at the $1 \%$ and $99 \%$ tails.

\subsection{Descriptive Statistics - Similarity of Winner vs. Runner-up}

Table 1 provides descriptive statistics on the 40 manufacturing plant opening events used in the analysis. Panel A shows that there are 43 and 59 winner and runner-up counties represented, implying that a few cases have more than one winner or runner-up localities. The cases are equally distributed between the former and the latter parts of the sample period. The distribution of the winner and runner-up counties among the Census regions shows that while the winners are concentrated in the South and West, the runner-up counties are more often located in the Northeast and Midwest regions of the US, consistent with Figure 1 and GHM (2010). ${ }^{22}$ I later examine whether the unbalanced geographical distribution introduces biases into estimates.

\section{[Insert Table 1 here.]}

Importantly, the average new plant in the sample accounts for $16 \%$ to $27 \%$ of total manufacturing output and labor forces of the winning county. Given the potential time lag between a plant opening and reaching the full operating capacity, these characteristics of the new plants are measured five years after the opening while those of the existing plants are measured one year prior to it (GHM, 2010). This relatively large size of the new plant

for the non-Census years. Plants with more than 250 employees are always included in the ASM while those with fewer employees are randomly sampled with the probability increasing in size.

${ }^{22}$ Census disclosure rules prevent me from breaking down the distribution of the winners and runners-up in further detail. 
suggests that its opening would significantly expand the local market for manufacturing jobs and reduce search costs for manufacturing workers in the winner county. ${ }^{23}$

[Insert Table 2 here.]

Table 2 shows firm-level characteristics for samples of public (i.e., Compustat) parent firms operating plants in the winner and runner-up counties (columns 1 and 2). All firm characteristics are measured one year prior to the plant opening. First, the first row shows that these firms have on average $25 \%$ of their workforces in the winner or counterfactual counties. Second, the comparison of columns 1 with 2 shows that observable firm characteristics including market leverage, asset size, market-to-book, and sales growth are well balanced between the firms in the two groups. In particular, $t$-statistics in column 5 indicate that a majority of the differences between firms in the winner and runner-up counties are statistically insignificant at a conventional level. ${ }^{24}$

This result contrasts with the significant differences between firms in the winner county and those neither in the winner nor runner-up counties in column 3. In fact, column 6 shows that the differences between the two groups are significantly different from zero for most of the variables. Hence, the descriptive analysis illustrates the advantage of using firms in the runner-up counties, rather than all other firms in Compustat, as a control group. In addition, I show in Online Appendix Table 1 that key plant-level characteristics are also statistically equivalent between the winner and runner-up counties prior to the plant opening, providing further support for the identifying assumption that the two counties are very similar.

\section{Empirical Analysis}

This section provides baseline estimates for the effect of large plant openings on firm capital structure, verifies a key assumption underlying the research design, and explores mechanisms.

\footnotetext{
${ }^{23}$ In computing these numbers, I exclude a few of the largest new plants in the sample, many of which have output and employees exceeding the aggregate values of the winner county, to provide a more representative estimate of the relative size of the new plants. Thus, these numbers are likely to underestimate the actual impact of the new plants on the local labor market.

24 Only the differences in book leverage and tangibility of assets are marginally significant but the economic magnitude is small.
} 


\subsection{Baseline Results}

I estimate the effects of the new manufacturing plant opening, which increases the size of manufacturing labor market in a county, on the capital structure of incumbent firms using the following difference-in-difference approach:

Leverage $_{i t}=\alpha_{i}+\alpha_{t}+\alpha_{e}+\beta_{1}$ After $_{i t} \times$ Winner $_{i t}+\beta_{2}$ After $_{i t}+\beta_{3}$ Winner $_{i t}+\gamma^{\prime} X_{i t}+\varepsilon_{i t}$,

where $\alpha_{i}$ is firm fixed effects, $\alpha_{t}$ is year fixed effects, $\alpha_{e}$ is plant-opening event fixed effects, Leverage $_{\text {it }}$ is book or market leverage (i.e., debt-to-capital) ratio defined as total debt (longterm plus short-term debt) divided by the sum of book or market value of equity and total debt, After ${ }_{\text {it }}$ is a dummy variable equal to one if the new plant opening has been announced by year $t$, and zero otherwise, Winner $_{i t}$ is a dummy variable equal to one if firm i operates plants in the winner county, and zero otherwise, ${ }^{25} \mathrm{X}_{\mathrm{it}}$ is a set of firm-level control variables, and $\varepsilon_{i t}$ is the residual for firm $\mathrm{i}$ in year $\mathrm{t}$. In the main specification, I include the plantopening event fixed effects (i.e., dummies for the 40 events). This specification generalizes the pairwise comparison of the winner and runner-up firms for each event in a regression framework. The time-varying firm-level control variables include (log) assets, tangibility of assets, market-to-book, and return on assets (ROA) as defined in Table 2 (Rajan and Zingales, 1995).

\section{[Insert Table 3 here.]}

Table 3 shows estimation results for equation (5). I use book leverage as the dependent variable in the main analysis and market leverage to examine the robustness of main results. Standard errors are clustered at the plant opening event level. Column 1 presents the baseline difference-in-difference estimates in which firms in the winner and runner-up counties and firms not in these counties are included. The column excludes the event fixed effects and firm-level financial controls. The coefficient on "After $\times$ Winner" shows that the leverage ratios of firms in the winner county increase by 3.01 percentage points after a plant opening relative to the leverage ratios of incumbent firms in the runner-

\footnotetext{
${ }^{25}$ Equation (5) estimates the coefficient on the dummy "Winner" as well as firm fixed effect because some firms switch in and out of the winner group across the plant opening events.
} 
up county. ${ }^{26}$ The coefficient is statistically significant at the $1 \%$ level. The relative increase in leverage ratio amounts to nearly $10 \%$ of the pre-event average leverage ratio $(33 \%)$.

In column 2, I include the firm-level controls and plant-opening event fixed effects. Adding these controls does not significantly alter the coefficient estimate on "After $\times$ Winner" which is 2.61 and statistically significant at the $1 \%$ level. This result indicates that the effect of a plant opening on leverage is unlikely to be driven by concurrent changes in the firm-level determinants of leverage or heterogeneity of events.

To control for time-varying industry-wide shocks, the specification in column 3 adds two-digit SIC industry $\times$ year fixed effects. The coefficient estimates and their statistical significance are very similar with those in column 2 , indicating that industry-level shocks are an unlikely driver of the result. In column 4, I check the robustness of the main estimate by using market leverage ratio as the dependent variable. In column 5, I restrict the estimation only to firms located in the winner or runner-up counties. Again, both columns show qualitatively similar estimates with those in columns 1 to $3 .^{27}$

Next, I examine whether the magnitude of the effect varies by the fraction of the incumbent firm's employees located in the winner or runner-up counties (i.e., treatment intensity). In particular, I split the sample of winner and runner-up firms into two equalsized groups at the median of the fraction of workers in the affected counties. I define the dummy variable "Large" ("Small") equal to one if the fraction is larger than (smaller than or equal to) the median, and zero otherwise. Then, I estimate the following regression which augments equation (5) with the interactions between the dummy variables "Large" and "Small" and dummy variables in equation (5):

$$
\begin{aligned}
& \text { Leverage }_{i t}=\alpha_{i}+\alpha_{t}+\alpha_{e}+\left(\beta_{1} \text { After }_{i t} \times \text { Winner }_{i t}+\beta_{2} \text { After }_{i t}+\beta_{3} \text { Winner }_{i t}\right) \times \text { Small }_{i t}+ \\
& \left(\beta_{4} \text { After }_{i t} \times \text { Winner }_{i t}+\beta_{5} \text { After }_{i t}+\beta_{6} \text { Winner }_{i t}\right) \times \text { Large }_{i t}+\gamma^{\prime} X_{i t}+\varepsilon_{i t} .
\end{aligned}
$$

Essentially, this specification separately estimates the effect of a plant opening on leverage for firms with relatively high and low treatment intensities. Table 4 shows that the

\footnotetext{
${ }^{26}$ The estimate on "After" (-0.640) suggests that existing firms in the runner-up counties slightly decrease leverage ratios after the opening, although the coefficient is insignificant ( $t$-stat $=-0.97)$. One possible explanation is that the runner-up firms slightly increased leverage prior to the plant opening decision with the expectation that the new plant might open in their county but levered down after the decision was made.

${ }^{27}$ In column 5, "NR" represents estimates that are not reported due to Census disclosure rules concerning sample size.
} 
effect of a plant opening is indeed statistically and economically significant for firms that have a large fraction of their employees in the affected counties while the effect is insignificant for firms with a small fraction of their labor in the counties. The first row shows that the estimate of "After $\times$ Winner $\times$ Large" is 4.21 and statistically significant at the $1 \%$ level. The estimate of "After $\times$ Winner $\times$ Small" is 1.02 and statistically insignificant. The difference between these two coefficients is significant at the $10 \%$ level $(t$-stat $=1.73)$.

[Insert Table 4 here.]

\subsection{Dynamic Effects of Plant Opening on Firm Leverage and Economic Magnitude}

I estimate the dynamic effects of a manufacturing plant opening on the capital structure of existing manufacturing firms using the following specification:

Leverage $_{i t}=\alpha_{i}+\alpha_{t}+\alpha_{e}+\sum_{k=-4}^{-2} \beta_{k}^{W}$ Winner $_{i t} \times d[t+k]_{i t}+\sum_{k=0}^{4} \beta_{k}^{W}$ Winner $_{i t} \times d[t+k]_{i t}+$ $\sum_{k=-4}^{-2} \beta_{k}^{R}$ Runner $-u p_{i t} \times d[t+k]_{i t}+\sum_{k=0}^{4} \beta_{k}^{R}$ Runner $-u p_{i t} \times d[t+k]_{i t}+\gamma^{\prime} X_{i t}+\varepsilon_{i t}$.

This specification is similar to that in equation (5) except that I replace the dummy variable "After" with the eight dummy variables " $\mathrm{d}[\mathrm{t}+\mathrm{k}]$," $-4 \leq \mathrm{k} \leq-2$ or $0 \leq \mathrm{k} \leq 4$, which equal to one for firm $i$ that operates in the winner or runner-up counties in four years before and after a new plant opening. ${ }^{28}$

[Insert Table 5 here.]

Table 5 shows the results of estimating equation (7). All estimates are from one regression equation but the coefficients on the event time dummies interacted with "Winner" and "Runner-up" are presented separately in columns 1 and 2, and column 3 shows the differences. The coefficients on "Winner $\times \mathrm{d}[\mathrm{t}+\mathrm{k}]$ " $(-4 \leq \mathrm{k}<0)$ show that there is no significant pattern of leverage for the winner firms before the plant opening ("year t-1" is the baseline year, and thus d[t - 1] is equal to zero by construction; see also GHM (2010) Table 4). Similarly, the coefficients on "Runner-up $\times \mathrm{d}[\mathrm{t}+\mathrm{k}]$ " $(-4 \leq \mathrm{k}<0)$ show an insignificant change for the runner-up firms before the plant opening. In column 3, I cannot reject the null hypothesis that each of the differences between the coefficients on "Winner $\times \mathrm{d}[\mathrm{t}+\mathrm{k}]$ " and "Runner-up $\times \mathrm{d}[\mathrm{t}+\mathrm{k}]$ " $(-4 \leq \mathrm{k}<0)$ is equal to zero. These estimates suggest that the

\footnotetext{
${ }^{28}$ Note that a dummy for "year t- 1 " is omitted in the estimation and thus all event time dummies represent leverage ratios relative to one year prior to the plant opening.
} 
leverage ratios of the winner and runner-up firms had statistically equivalent trends before the plant decided to open. This evidence lends credibility to the identifying assumption that firms operating plants in the two counties are similar ex ante.

In contrast, the coefficients on "Winner $\times \mathrm{d}[\mathrm{t}+\mathrm{k}]$ " $(0 \leq \mathrm{k} \leq 4)$ show that the leverage ratios of winner firms begin to increase from the year of the plant opening ("year t”). For example, one year after the plant opening, the leverage of the winners increases by 2.23 percentage points on average, compared to one year prior to the opening (significant at the $1 \%$ level). The coefficients on "(Winner - Runner-up) $\times \mathrm{d}[\mathrm{t}+\mathrm{k}]$ " $(0 \leq \mathrm{k} \leq 4)$ show that the leverage ratios of the winners increase significantly relative to those of the runners-up after the plant opening. Figure 2 depicts the dynamics of leverage based on the estimates in Table 5.

\section{[Insert Figure 2 here.]}

How big is the economic magnitude of the plant opening effect on leverage ratios? In Table 6, I compare the impact of a typical plant opening in the sample on the leverage of incumbent firms with that of a typical change in other determinants of leverage.

\section{[Insert Table 6 here.]}

Based on the coefficient estimates in Table 5, the table shows that a one standard deviation change in each of the common determinants of financial leverage is associated with a change in leverage ratio of 0.75 to 4.17 percentage points in absolute value. In comparison, four years after the opening of a typical plant in the sample, leverage of the

firms in the winner county increases by 3.90 percentage points relative to the runner-up. The absolute magnitude of this effect is larger than that of a leverage change due to a typical change in tangibility, market-to-book, or return on assets.

\subsection{Labor Market Size and Wage Loss of Displaced Workers}

In this section, I test an important assumption underlying my research design: The larger a local labor market, the smaller wage losses that workers experience after a job displacement (due to reduced search frictions). Following the literature (e.g., Gibbons and Katz, 1991), I define an exogenous job displacement as a worker's change in employer due 
to "mass layoffs" after plant closings, which are identified using the LBD. ${ }^{29}$ Consistent with the earlier analysis, I focus on a $20 \%$ random sample of workers displaced from manufacturing industries from 1991 to $2005^{30}$ and use the number of plants (i.e., employers) at the two-digit SIC industry and county level as a proxy for labor market size. Then, I use worker-year observations with the measure of labor market size larger than its median ${ }^{31}$ because a marginal change in the number of plants is unlikely to affect alternative employment opportunities of workers in very large labor markets where many potential employers exist. I obtain worker-level wages and characteristics information from the LEHD data, and construct a control group of workers by choosing a 1\% random sample of the LEHD workers in manufacturing who are not displaced (Jacobson et al., 1993). I estimate the wage dynamics around the year of job displacement relative to workers who are not displaced as follows:

$\log (\text { wage })_{i t}=\alpha_{i}+\alpha_{t}+\sum_{k=-3}^{4} d[t+k]_{i t} \delta_{k}+\sum_{k=-3}^{4} d[t+k]_{i t} \times D S_{i t} \theta_{k}+\sum_{k=-3}^{4} d[t+k]_{i t} \times$ $D S_{i t} \times \log (\# \text { plants })_{i t} \beta_{k}+\gamma^{\prime} X_{i t}+\varepsilon_{i t}$,

where $\alpha_{i}$ is worker fixed effects, $\alpha_{t}$ is year fixed effects, $\log (\text { wage })_{i t}$ is log annual real wage, $\mathrm{d}[\mathrm{t}$ $+\mathrm{k}]_{\mathrm{it}},-3 \leq \mathrm{k} \leq 4$ is a dummy variable equal to one if worker $\mathrm{i}$ is in three years before and four years after a job displacement (or for the control group of workers, it is a dummy variable equal to one if the worker is in three years before and four years after a randomly selected year), and zero otherwise, $\mathrm{DS}_{\text {it }}$ is a dummy variable equal to one if worker $\mathrm{i}$ is displaced from a job, and zero otherwise, $\log (\# \text { plants })_{\text {it }}$ represents the log number of plants in the same industry located in a displaced worker i's county, $\mathrm{X}_{\mathrm{it}}$ is a set of worker-level control variables, including interaction terms between sex and education, and work experience, and $\varepsilon_{\mathrm{it}}$ is the residual for worker $\mathrm{i}$ in year $\mathrm{t}$. Standard errors are adjusted for sample clustering at the two-digit SIC industry and county level.

\section{[Insert Table 7 here.]}

Column 1 of Table 7 shows that on average, one year and two years after job displacement, the log wage loss for displaced workers amounts to $55.3 \%$ (= 1 -exp $(-0.805))$

${ }^{29}$ Job losses initiated by a plant closing are considered exogenous in that workers' ability or skills are much less likely to affect firing decisions in mass layoffs (Gibbons and Katz, 1991).

30 The $20 \%$ random sampling is to reduce computational burden in estimating the wage equation below, and is innocuous for the results.

${ }^{31}$ Due to the Census disclosure rules, I am unable to report medians of variables. 
and $32.4 \%$ of their pre-displacement annual wages. These magnitudes are comparable with previous research (e.g., Jacobson et al., 1993; Couch and Placzek, 2010). Importantly, column 2 shows that the wage loss is significantly smaller when the relevant local labor market is larger. A one standard deviation (1.25) increase in local market size leads to a $8.1 \%$ and $8.4 \%$ reduction in the magnitude of wage loss one and two years after displacement, respectively. These magnitudes represent $14.7 \%$ to $26.0 \%$ of the average wage loss for displaced workers in those years post job displacement. In addition, column 3 estimates equation (8) by employing another proxy for local labor market size: the number of workers in a given industry and county. However, the estimates on " $\mathrm{d}[\mathrm{t}+\mathrm{k}] \times \mathrm{DS} \times \log$ (\#workers)" $(k \geq 1)$ are insignificant. The weak effect of this proxy may be because the number of workers is also correlated with the degree of competition for similar jobs, mitigating the effect of market size. ${ }^{32}$

Moreover, I find evidence that the mechanism through which large labor markets mitigate displaced workers' wage loss is by allowing them to stay within the same industry after a job loss (unreported). Specifically, I find that the probability of a displaced worker to stay in the same two-digit SIC industry increases by $9.1 \%$ as local market size increases by one standard deviation (significant at the $5 \%$ level). This result is consistent with the notion that when there are more potential jobs using the same type of skills, workers can maintain their specific skills and wage levels (Neal, 1995). In sum, the analysis in this section shows that the size of a local labor market provides significant variation in workers' personal cost of job loss, which in turn affects indirect costs of financial distress.

\subsection{Mechanisms for the Effects}

In this section, I explore mechanisms driving the effects of large plant openings on firm leverage.

\subsubsection{Labor Market Size vs. Other Mechanisms of Agglomeration}

\footnotetext{
32 Consistent with this result, Online Appendix A shows that the number of workers in the local market is statistically and economically less significantly associated with firm leverage, compared with the number of plants as a proxy for labor market size.
} 
Previous research on labor mobility and specific human capital shows that some skills are not transferrable across different employers (e.g., Jacobson et al., 1993; Lazear, 2009). Thus, if the effects I find are driven by an expansion of the local market for manufacturing labor, a plant opening would have a larger impact on existing firms that employ workers who have similar skills with the new plant. ${ }^{33}$

I test this prediction by using two empirical approaches. First, I measure the similarity of labor skills using detailed industry classifications (Neal, 1995). Specifically, using the Census LBD data, I compute the fraction of a given firm's employees that are in the same two-digit SIC industry as the new plant. Then, I estimate the effect of a plant opening separately for firms with the fraction above and below the top $30 \%$ of the distribution ${ }^{34}$ using an empirical specification similar to equation (6). Columns 1 and 2 in Table 8 show that for firms with a significant fraction of employees in the same industry as the new plant, the effect of the plant opening on leverage is 5.68 and statistically significant at the $1 \%$ level while it is insignificant at 1.34 for firms with most employees in different industries. The difference between the two groups is significant at the $10 \%$ level $(t$-stat $=1.80)$.

[Insert Table 8 here.]

In the second approach, I measure the similarity of labor skills between two industries using the LEHD data. Specifically, for a pair of two-digit SIC industries within manufacturing, I compute the fraction of worker flows from a job in one industry to another (see GHM (2010); Tate and Yang (2015b) for similar approaches). Then, I estimate the effect of a plant opening separately for firms with the fraction of worker movements above and below the top 30\% of the distribution. Columns 3 and 4 show that the effect on leverage is significant only when there are meaningful worker flows between the industries of the new plant and the existing firms ("After $\times$ Winner" $=6.62 ; t$-stat $=2.88$ ). The difference between firms with relatively high vs. low levels of labor flows is significant at the $5 \%$ level $(t$-stat $=2.13)$.

The finding that a new plant affects the capital structure of local firms that share similar workers supports the role of the "thick labor markets" channel as a micro mechanism

${ }^{33}$ In the model in Section 2, a plant opening represents a decrease in the parameter $u$ for firms that use similar skills with the new plant.

34 A relatively higher cutoff is preferred to the median given that the fraction is close to zero for a bulk of firms. 
of agglomeration economies. ${ }^{35}$ Moreover, this paper documents for the first time that increased debt usage in large labor markets is another benefit of firm clustering, such as improved incentives for managers (Harris and Raviv, 1990) and interest tax deductions (Graham, 2000).

One related concern, however, is that other mechanisms of agglomeration spillovers may be driving the increase in leverage that I find. In particular, the agglomeration economies literature points out two main mechanisms other than labor market size: proximity to suppliers and buyers, and knowledge spillovers (e.g., Moretti, 2011). For example, if some of the existing plants buy or sell intermediate goods from or to the new plant, or share similar technologies with it, the plant opening may lead to an increase in productivity of existing plants (GHM, 2010).

However, it is theoretically unclear how the plant opening would affect capital structure of firms operating the existing plants through these alternative channels. Moreover, following Ellison, Glaeser, and Kerr (2010), I examine whether the effect of the plant opening is more pronounced when the existing firms and new plant i) ship goods to each other, or ii) share similar technologies. ${ }^{36}$ If the increase in leverage is somehow due to these two mechanisms, the estimates would be more pronounced when the new plant-existing firm pair is more "connected" in these dimensions. Inconsistent with these channels, however, neither input-output relationship nor technological similarity is significantly associated with the effect of the plant opening on leverage (columns 5 to 8 in Table 8). If anything, the effect is somewhat pronounced when the new plant is not a buyer or supplier of existing plants.

\subsubsection{Marginal Benefit of Leverage}

I investigate whether changes in leverage are consistent with a trade-off model of capital structure. In particular, do firms with larger marginal benefits of debt increase leverage more in response to a reduction in the cost of financial distress, which is driven by

\footnotetext{
${ }^{35}$ See Glaeser and Gottlieb (2009) for a review of the literature on agglomeration economies.

36 The input-output relationship between a pair of three-digit SIC industries is calculated using the Bureau of Economic Analysis (BEA) 1987 Benchmark Input-Output Accounts, and the extent to which technologies are related between a pair of three-digit SIC industries using the NBER Patent Database. See Ellison et al. (2010) for details.
} 
an expansion of the labor market? To answer this question, I examine the role of unexploited tax benefits of debt because i) theories assume that debt tax shield is one of the key benefits of leverage (Miller, 1977; Hennessy and Whited, 2005) and ii) quantifying the magnitude of tax benefits is feasible using available methods. Following the literature, I use firm-specific marginal tax rates (MTRs) to measure marginal tax benefits of leverage (Graham, 2000). Given that an additional tax benefit of levering up is larger for firms with higher MTRs, a reduction in the cost of financial distress would lead those firms to lever up more than firms with lower MTRs, other things held constant. ${ }^{37}$ I define firms as high- (low-) MTR firms if their marginal tax rates are equal to (lower than) the statutory rate.

[Insert Table 9 here.]

Consistent with the prediction, Table 9 shows that firms with high MTRs increase leverage ratios by 3.33 percentage points which is statistically significant at the $1 \%$ level while the effect is close to zero $(-0.37)$ for firms with low MTRs. The difference in coefficients on "After $\times$ Winner" between the high- and low-MTR groups is statistically significant at the $10 \%$ level $(t$-stat $=1.74)$.

\subsubsection{How Does Labor Market Size Affect Costs of Financial Distress?}

The results in the previous sections are consistent with the argument that an increase in labor market size reduces the cost of financial distress which in turn increases the optimal leverage ratio. What might drive this cost of financial distress? The conceptual framework in Section 2 suggests that compensation premium for job loss risk is the cost of financial distress affecting leverage. For example, when a worker has invested in specific skills, she would require a premium for wage loss risk if the firm is highly levered (Titman, 1984; Berk et al., 2010). Given that a large market reduces the risk of wage loss (see Section 5.3), wage premium will decrease after a plant opening. However, after the plant opening, firms increase leverage which tends to increase wage premia (Graham et al., 2015), and thus the net effect of market size on wages is ambiguous and ultimately an empirical question (see equation (3)).

\footnotetext{
${ }^{37}$ This prediction is equivalent to varying $T^{\prime}(L)$ in the first-order condition in equation (4).
} 
To empirically examine this question, I estimate the effect of a plant opening on wages and labor productivity using the ASM and CMF databases and the following difference-in-difference approach:

Outcome $_{i t}=\alpha_{i}+\alpha_{j \times t}+\alpha_{e}+\beta_{1}$ After $_{i t} \times$ Winner $_{i t}+\beta_{2}$ After $_{i t}+\beta_{3}$ Winner $_{i t}+\gamma^{\prime} X_{i t}+\varepsilon_{i t}$,

where $\alpha_{i}$ is plant fixed effects, $\alpha_{j \times t}$ is three-digit SIC industry $\times$ year fixed effects (where $j$

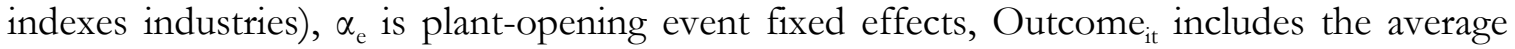
wage of workers, per-hour wages, and labor productivity, defined as output scaled by total work hours, all dummies are defined as in equation (5), $\mathrm{X}_{\mathrm{it}}$ is a set of plant-level control variables including the log numbers of plants in a given firm and segment in the firm, and $\varepsilon_{\text {it }}$ is the residual for plant $\mathrm{i}$ in year t. Plant-year observations from five years before and after a plant opening are included in the analysis.

[Insert Table 10 here.]

Table 10 presents estimation results for equation (9). Columns 1 and 2 show that after a plant opening, there is no significant change in wages at the plants in the winner vs. runner-up counties. In contrast, column 3 shows that labor productivity increases significantly by $3.1 \%$ at existing plants in the winner county relative to the runner-up county. This insignificant wage change, combined with significant productivity gains, is consistent with the model in Section 2 as well as theories of local labor markets (e.g., Moretti, 2011). On the one hand, workers would require smaller compensating differentials for wage loss risk in a larger market which decreases wages. Although not explicitly modeled in this paper, a larger labor market could also incentivize workers to invest in skills and be more productive, which pushes up equilibrium wages (Rotemberg and Saloner, 2000; Almazan et al., 2007). On the other hand, firms increase leverage after a labor market expands which in turn increases wages. ${ }^{38}$

\section{Alternative Explanations and Robustness}

This section examines the validity of leading alternative explanations and the robustness of the baseline results using complementary empirical approaches.

\footnotetext{
${ }^{38} \mathrm{I}$ focus on these two forces given prior research suggesting that medium to long-term equilibrium wages are likely driven by compensating differentials and labor productivity instead of other forces such as imbalance in labor supply and demand (e.g., Blanchard and Katz, 1992).
} 


\subsection{Collateral Channels: Property Values}

In this section, I address an alternative explanation concerning collateral channels. Greenstone and Moretti (2004) show that counties that successfully attract new plants experience a significant increase in property values. Hence, an alternative explanation is that a concurrent increase in property collateral values drives the increase in leverage (Shleifer and Vishny, 1992; Chaney et al., 2012). I address this alternative channel by directly controlling for county-level property values in equation (5). ${ }^{39}$ In Online Appendix Table 2, I find that while the log property value has a positive (but insignificant) coefficient, the magnitude of "After $\times$ Winner" is very similar and significant at the $5 \%$ level whether the property value is included in the regression or not (2.95 vs. 3.00$)$.

\subsection{Geographical Distribution of Winner and Runner-up Counties}

Figure 1 and Table 1 show that the runner-up localities are relatively concentrated in the Northeast and Midwest, and the winners are clustered in the South and West of the US. This uneven spatial distribution could raise the concern that omitted economic factors specific to regions may drive firm capital structure decisions. To address this concern, I estimate the effect of a plant opening conditional on whether both counties in a given event are in the same Census region or not. There are 19 events with the two counties in the same region out of 40 in the sample. Online Appendix Table 3 shows that estimates for "After $\times$ Winner" are very similar between the two groups (2.60 vs. 2.73$).^{40}$

\subsection{Increased Labor Cost}

Another alternative explanation is that increased labor demand in the winner county leads firms to increase their debt usage in part to finance higher wage bills (assuming local labor supply is upward-sloping). However, as shown in Section 5.4.3, there is no significant change in wages at plants in the winner vs. runner-up counties. Moreover, at a theoretical

\footnotetext{
${ }^{39}$ I hand-collect data on county-level property values from the Census of Governments, Volume 2 Taxable Property $V$ alues and Assessment-Sales Price Ratios, published in 1977, 1982, 1987, and 1992.

40 The low level of statistical significance for the "Same" group is in part due to a small number of events in the group (19). If I were to increase the number of events to that of the full sample (40), the coefficients on "After $\times$ Winner" could be significant at a conventional level.
} 
level, debt is less suitable than equity to finance wages because a higher labor cost increases the firm's operating leverage (e.g., Schmalz, 2015). Given the trade-off between operating and financial leverages (Mauer and Triantis, 1994), an increase in expected wages would lead to a decrease, as opposed to an increase, in optimal financial leverage.

\subsection{Bargaining with Employees}

An alternative channel is that a plant opening increases employees' bargaining power by improving job opportunities in the local market. If this is the case, firms in the winner county may increase financial leverage to improve their bargaining position in wage setting (Bronars and Deere, 1991; Matsa, 2010). However, it is not theoretically clear whether a plant opening would increase workers' bargaining power, which is considered to be driven by such things as (threat of) unionization, uniqueness of labor skills, and importance of labor to the firm (Mishel, 1984; Katz, Kochan, and Colvin, 2008). Rather, a plant opening is more likely to increase employees' outside options by reducing labor market slack. ${ }^{41}$

Hence, whether a plant opening increases labor bargaining power and in turn the firm's leverage is an empirical question, which I answer using measures of labor bargaining power and "rents": unionization rates and firm profits (e.g., Mishel, 1984; Blanchflower et al., 1996). ${ }^{42}$ If a new plant increases existing workers' bargaining power (hence leverage), the effect would be more pronounced in highly unionized or profitable firms. Online Appendix Table 4 shows that a plant opening leads to an insignificant change in leverage for highlyunionized industries (by $0.42 ; t$-stat $=0.24$ ) but leads to a significant increase in leverage for industries with low union coverage (by 3.28; $t$-stat $=3.94$ ). ${ }^{43}$ Similarly, there is no support for the bargaining channel when I sort firms into two groups at the median of return on assets, a measure of firm profitability. The magnitude of leverage changes is not larger for firms with

\footnotetext{
${ }^{41}$ In fact, rent sharing models of wages typically consider workers' outside option as a separate force from the bargaining power in wage determination. For example, Mortensen's (2003) bilateral bargaining model shows that equilibrium wages, $w(p)=b+\beta(p-b)$, where $b$ and $\beta$ represent the worker's outside option and bargaining power, respectively, and $p$ represents productivity.

42 Blanchflower et al. (1996, p.241) state, "Explaining how such [rent] sharing can happen in the absence of unions is a theoretical challenge." And higher profits likely mean a pool of funds from which unions can gain higher wages (Mishel, 1984).

${ }^{43}$ I follow Matsa (2010) and use 25\% as the cutoff to define industries with high- and low-collective bargaining coverage. Data on union coverage are obtained from Hirsch and Macpherson (2003).
} 
high vs. low profitability (coefficient $=1.69 ; t$-stat $=1.66$ vs. coefficient $=3.50 ; t$-stat $=2.72$ ). Hence, both tests are inconsistent with the bargaining power hypotheses.

\subsection{Countywide Shocks}

Another concern is that local-level economic or financial shocks that coincide with the plant opening may drive the increase in leverage. I address this concern by estimating the effect of a manufacturing plant opening on the leverage of incumbent non-manufacturing firms in the county, and vice versa. If countywide shocks drive the effect, then it would likely hold independent of the sector. In Online Appendix Table 5, I show that both the effect of a large manufacturing plant opening on existing non-manufacturing firms and that of a large non-manufacturing establishment opening on existing manufacturing firms ${ }^{44}$ are insignificant. This result suggests that a new establishment has no impact on the leverage of incumbent firms in different economic sectors.

\subsection{MSA-level Result}

In Online Appendix Table 6, I find that when a new plant opens, incumbent firms in the winner MSA increase their leverage ratios by 0.83 percentage points compared to those in the runner-up MSA. This estimate is imprecise with an associated $t$-statistic of 1.52. The weaker effect at the MSA level compared to the county level suggests that a more appropriate definition of a local labor market may be a county rather than a greater metropolitan area.

\section{Conclusion}

I investigate how the size of labor markets affects the capital structure choices of firms through changes in the costs of financial distress arising from workers' limited ability to move across jobs. To examine this relation, I use the opening of a large manufacturing plant in a given county as an abrupt increase in local market size for manufacturing labor. My estimates indicate that after a plant opening, existing manufacturing firms in the county

${ }^{44}$ To perform this analysis, I collect 18 cases of large non-manufacturing establishment openings such as retail warehouses and utilities operation centers from Site Selection and the SSEL and LBD databases following the procedure described in Section 4.1. 
increase their leverage ratios by 2.6 to 3.9 percentage points while firms in an otherwise comparable county do not change their capital structure in this way. Additional analysis shows that plant openings have a larger impact on firms that are more likely to use the same type of labor as the new plant. Overall, the evidence suggests that the size of labor markets in which firms operate is an important determinant of the costs of using financial leverage and hence, the capital structure decisions of firms. 


\section{References}

Abowd, John M. and Orley C. Ashenfelter, 1981, Anticipated Unemployment, Temporary Layoffs, and Compensating Wage Differentials, NBER Chapters, in: Studies in Labor Markets, 141-186.

Acemoglu, Daron, 1997, Training and Innovation in an Imperfect Labour Market, Review of Economic Studies 64, 445-464.

Agrawal, Ashwini K. and David A. Matsa, 2013, Labor Unemployment Risk and Corporate Financing Decisions, Journal of Financial Economics 108, 449-470.

Almazan, Andres, Adolfo De Motta, and Sheridan Titman, 2007, Firm Location and the Creation and Utilization of Human Capital, Review of Economic Studies 74, 13051327.

Almeida, Heitor and Thomas Philippon, 2007, The Risk-Adjusted Cost of Financial Distress, Journal of Finance, 62, 2557-2586.

Benmelech, Efraim, Nittai Bergman, and Ricardo J. Enriquez, 2012, Negotiating with Labor under Financial Distress, Review of Corporate Finance Studies 1, $28-67$.

Berk, Jonathan B., Richard Stanton, and Josef Zechner, 2010, Human Capital, Bankruptcy and Capital Structure, Journal of Finance 65, 891-926.

Blanchard, Oliver J. and Lawrence F. Katz, 1992, Regional Evolutions, Brookings Papers on Economic Activity 1, 1-75.

Blanchflower, David, Andrew Oswald, and Peter Sanfey, 1996, Wages, Profits, and RentSharing, Quarterly Journal of Economics 111, 227-251.

Bronars, Stephen G. and Donald R. Deere, 1991, The Threat of Unionization, the Use of Debt, and the Preservation of Shareholder Wealth, Quarterly Journal of Economics 106, 231-254.

Brown, Jennifer and David A. Matsa, 2015, Boarding a Sinking Ship? An Investigation of Job Applications to Financially Distressed Firms, Journal of Finance Forthcoming.

Chaney, Thomas, David Sraer, and David Thesmar, 2012, The Collateral Channel: How Real Estate Shocks Affect Corporate Investment, American Economic Review 102, 2381-2409.

Couch, Kenneth A. and Dana W. Placzek, 2010, Earnings Losses of Displaced Workers Revisited, American Economic Review 100, 572-589.

Davis, Morris A., Jonas D. M. Fisher, and Toni M. Whited, 2014, Macroeconomic Implications of Agglomeration, Econometrica 82, 731-764.

Diamond, Peter A., 1982, Aggregate Demand Management in Search Equilibrium, Journal of Political Economy 90, 881-894.

Duranton, Gilles and Diego Puga, 2004, Micro-foundations of urban agglomeration economies, Handbook of Regional and Urban Economics, in: J. V. Henderson \& J. F. Thisse (ed.), Chapter 48, 2063-2117.

Ellison, Glenn, Edward L. Glaeser, and William R. Kerr, 2010, What Causes Industry Agglomeration? Evidence from Coagglomeration Patterns, American Economic Review 100, 1195-1213.

Gibbons, Robert and Lawrence Katz, 1991, Layoffs and Lemons, Journal of Labor Economics 9, 351-380. 
Glaeser, Edward L. and Joshua D. Gottlieb, 2009, The Wealth of Cities: Agglomeration Economies and Spatial Equilibrium in the United States, Journal of Economic Literature 47, 197-228.

Glaeser, Edward L. and Janet E. Kohlhase, 2004, Cities, Regions and the Decline of Transportation Costs, Papers in Regional Science 83, 197-228.

Glaeser, Edward L. and David C. Maré, 2001, Cities and Skills, Journal of Labor Economics 19, 316-342.

Graham, John R., 2000, How Big are the Tax Benefits of Debt?, Journal of Finance 55, 1901-1941.

Graham, John R., Hyunseob Kim, Si Li, and Jiaping Qiu, 2015, The Reallocative Employee Costs of Corporate Bankruptcy, Unpublished.

Greenstone, Michael, Richard Hornbeck, and Enrico Moretti, 2010, Identifying Agglomeration Spillovers: Evidence from Winners and Losers of Large Plant Openings, Journal of Political Economy 118, 536-598.

Greenstone, Michael and Enrico Moretti, 2004, Bidding for Industrial Plants: Does Winning a 'Million Dollar Plant' Increase Welfare?, NBER Working Paper 9844.

Harris, Milton and Artur Raviv, 1990, Capital Structure and the Informational Role of Debt, Journal of Finance 45, 321-349.

Hennessy, Christopher A. and Toni M. Whited, 2005, Debt Dynamics, Journal of Finance 60, 1129-1265.

Hirsch, Barry T. and David A. Macpherson, 2003, Union Membership and Coverage Database from the Current Population Survey: Note, Industrial and Labor Relations Review 56, 349-354.

Jacobson, Louis S., Robert J. LaLonde, and Daniel G. Sullivan, 1993, Earnings Losses of Displaced Workers, American Economic Review 83, 685-709.

Katz, Harry C., Thomas A. Kochan, and Alexander J. S. Colvin, 2008, An Introduction to Collective Bargaining and Industrial Relations, Fourth Edition, McGraw-Hill, New York, NY.

Lazear, Edward P., 2009, Firm-Specific Human Capital: A Skill-Weights Approach, Journal of Political Economy 117, 914-940.

Matsa, David A., 2010, Capital Structure as a Strategic Variable: Evidence from Collective Bargaining, Journal of Finance 65, 1197-1232.

Mauer, David C. and Alexander J. Triantis, 1994, Interactions of Corporate Financing and Investment Decisions: A Dynamic Framework, Journal of Finance 49, 1253-1277.

Miller, Merton H., 1977, Debt and Taxes, Journal of Finance 32, 261-275.

Mishel, Lawrence, 1984, The Structural Determinants of Union Bargaining Power, Industrial and Labor Relations Review 40, 90-104.

Moretti, Enrico, 2011, Local labor markets, Handbook of Labor Economics 4B, in: D. Card \& O. Ashenfelter (ed.), Chapter 14, 1237-1313.

Mortensen, Dale T., 2003, Wage Dispersion, MIT Press, Cambridge, MA.

Neal, Derek, 1995, Industry-Specific Human Capital: Evidence from Displaced Workers, Journal of Labor Economics 13, 653-677.

Pagano, Marco and Paolo Volpin, 2008, Labor and Finance, Unpublished.

Petrongolo, Barbara and Christopher A. Pissarides, 2006, Scale Effects in Markets with Search, The Economic Journal 116, 21-44. 
Rajan, Raguram G. and Luigi Zingales, 1995, What Do We Know About Capital Structure? Some Evidence from International Data, Journal of Finance 50, 1421-1460.

Rotemberg, Julio R. and Garth Saloner, 2000, Competition and Human Capital Accumulation: A Theory of Interregional Specialization and Trade, Regional Science and Urban Economics 30, 373-404.

Schmalz, Martin C., 2015, Unionization, Cash, and Leverage, Unpublished.

Sharpe, Steven, 1994, Financial Market Imperfections, Firm Leverage, and the Cyclicality of Employment, American Economic Review 84, 1060-1074.

Shleifer, Andrei and Robert W. Vishny, 1992, Liquidation Values and Debt Capacity: A Market Equilibrium Approach, Journal of Finance 47, 1343-1366.

Sjaastad, Larry A., 1962, The Costs and Returns of Human Migration, Journal of Political Economy 70, 80-93.

Tate, Geoffrey A. and Liu Yang, 2015a, The Bright Side of Corporate Diversification: Evidence from Internal Labor Markets, Review of Financial Studies 28, 2203-2249.

Tate, Geoffrey A. and Liu Yang, 2015b, The Human Factor in Acquisitions: Cross-industry Labor Mobility and Corporate Diversification, Unpublished.

Titman, Sheridan, 1984, The Effect of Capital Structure on a Firm's Liquidation Decision, Journal of Financial Economics 13, 137-151. 
Figure 1: Location of Manufacturing Plant Opening Events across the US

This figure shows the approximate location of the counties in which new manufacturing plants opened ("winners"; blue solid circles) and the plants' runnerup choices ("runners-up"; red dotted circles). There are 60 events represented in the figure, among which 40 are matched with the US Census Bureau's establishment-level datasets. A detailed list of the 60 events is available upon request.

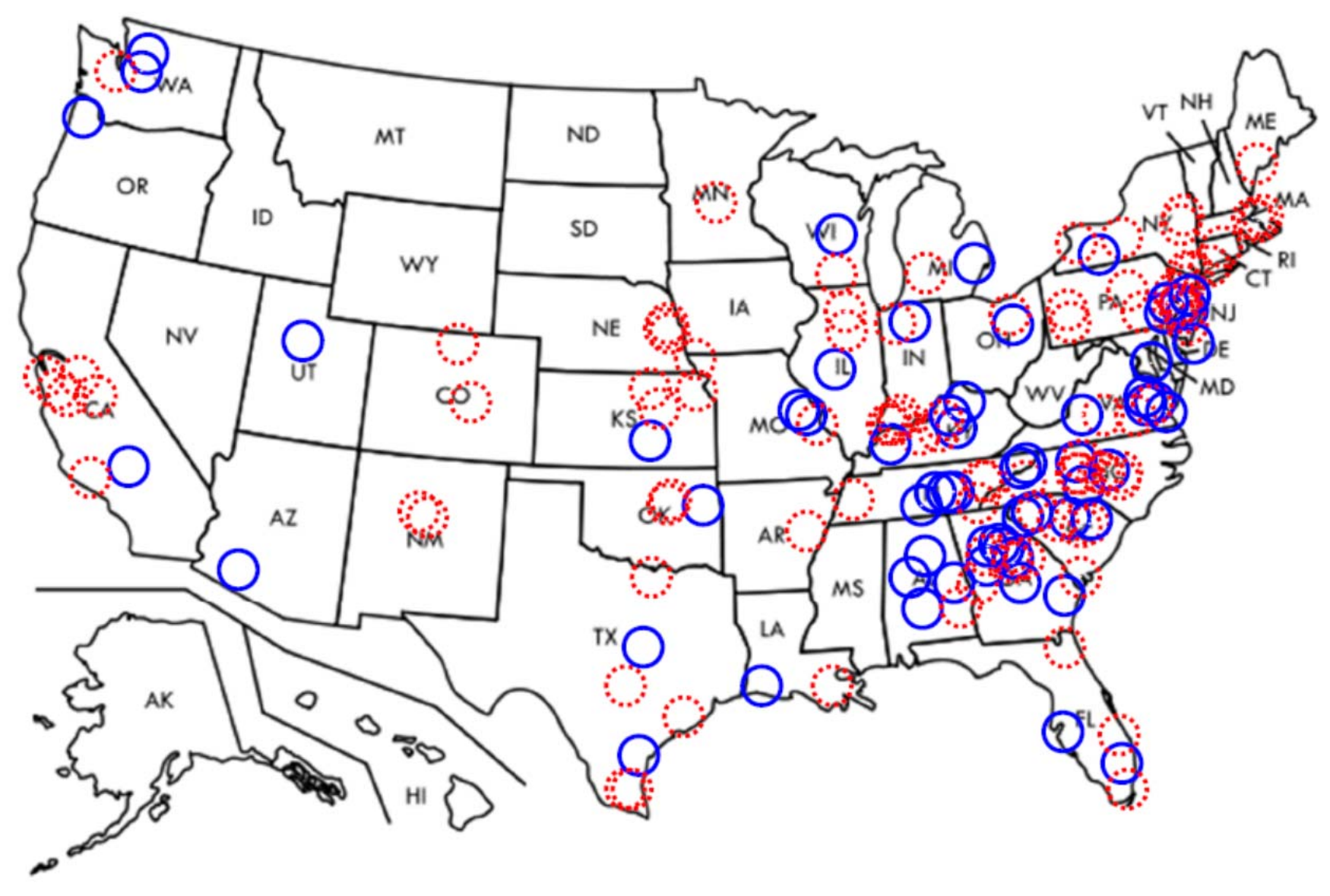




\section{Figure 2: Dynamic Effects of Manufacturing Plant Opening on Leverage of Existing Manufacturing Firms}

This figure shows the dynamics of book leverage ratios for firms operating in the counties in which new manufacturing plants opened ("winner") and firms operating in the counties that were top candidates for the plant sites but lost the competition ("runner-up") from four years before and after the plant opening. The firms that are the owners of the new plants are excluded from both the winner and runner-up groups.

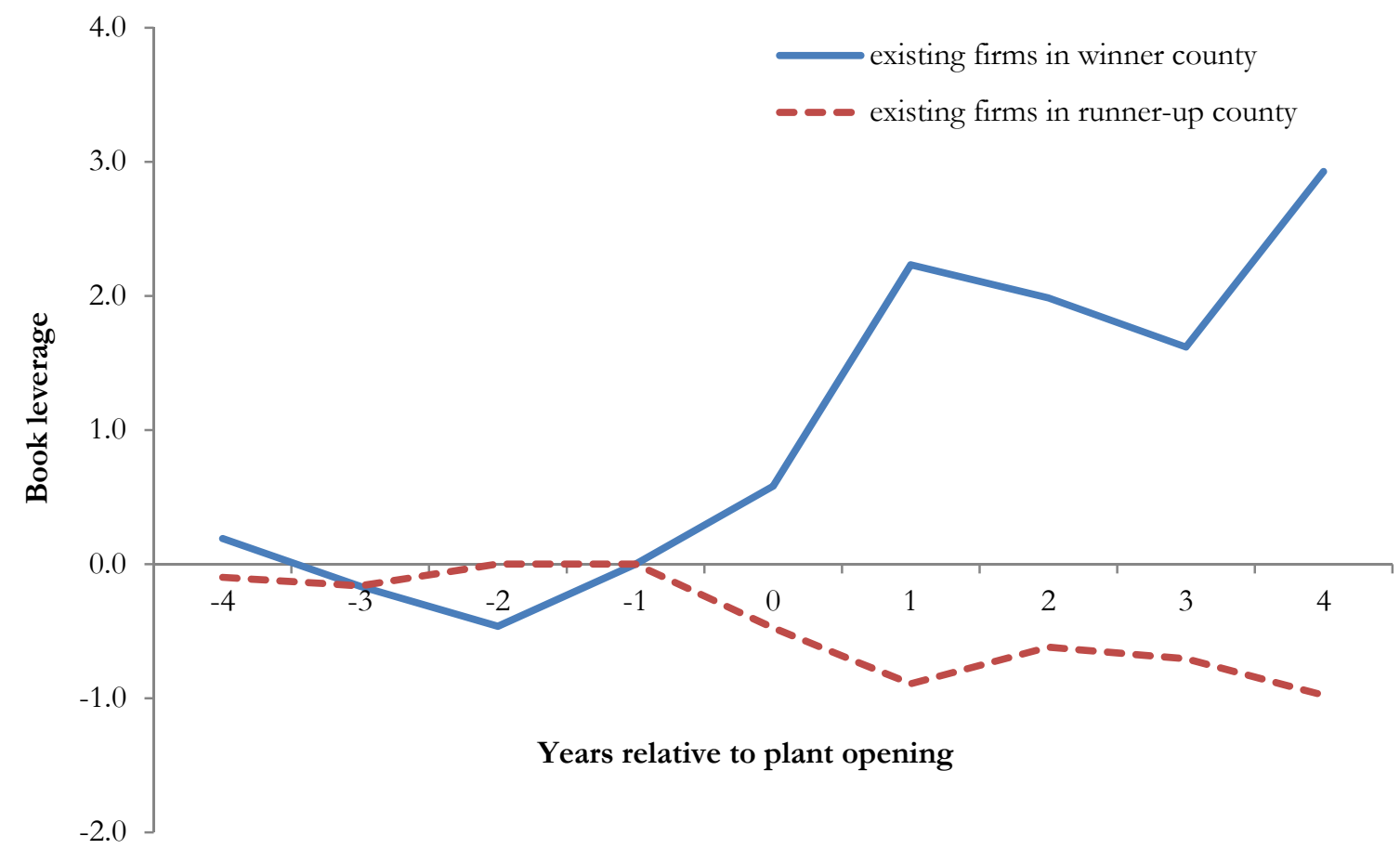




\section{Table 1: Summary Statistics on Manufacturing Plant Opening Events}

This table presents descriptive statistics on the events of manufacturing plant openings drawn from various issues of Site Selection from 1980 to 1995. It shows the numbers of plant opening events and the winner and runner-up counties that could be matched to establishment-level Census data for the full sample, by time period, and by Census region. Census confidentiality rules prevent me from presenting the distribution of the events in more detail. The average and standard deviation (in parentheses) of key characteristics of the new plants are shown as a fraction of those of the winner counties as a whole obtained from the ASM and CMF databases. Characteristics of the new plants are measured five years after the opening and those of the winner counties are measured one year prior to it. "Output" is total value of shipment scaled by an output price index; "Total employees" is the number of employees; and "Production worker hours" is total production worker hours employed by the plant.

\begin{tabular}{lc}
\hline \hline & $(1)$ \\
\hline Total number of events & 40 \\
Total number of winner counties & 43 \\
Total number of runner-up counties & 59 \\
& \\
Distribution of events by year: & \\
1980-87 & 20 \\
$1988-95$ & 20 \\
& \\
Distribution of winner counties by region: & \\
Northeast \& Midwest & 10 \\
South \& West & 33 \\
Distribution of runner-up counties by region: & \\
Northeast \& Midwest & 25 \\
South \& West & 34 \\
New plants relative to winner counties: & \\
Output & \\
Total employees & 0.16 \\
Production worker hours & $(0.19)$ \\
& 0.27 \\
\hline \hline
\end{tabular}




\section{Table 2: Summary Statistics on Firm Observations}

This table provides descriptive statistics for firm-year observations from Compustat in the manufacturing industries (SIC codes $2000-3999$ ) from 1975 to 2000. Columns "Winner" and "Runner-up" show the statistics for firms that operate in the winner and runner-up counties, respectively, and column "All other firms" shows the statistics for all firms not located in the winner or runner-up counties. "\% employees in winner/runner-up counties" represents the fraction of the firm's total workforce located in the winner or runner-up counties; "Book leverage" is defined as total debt (long-term plus short-term debt) divided by the sum of total debt and book value of equity; "Market leverage" is defined as total debt divided by the sum of total debt and market value of equity; "Cash holdings" is cash and equivalents divided by total assets; "Log assets" is log book assets in million dollars; "Tangibility" is net value of plant, property, and equipment divided by total assets; "Market-to-book" is total assets minus book equity plus market equity scaled by total assets; "Return on assets" is operating income before depreciation and amortization scaled by lagged assets; "Labor intensity" is computed as the number of total employees divided by real assets in constant 2000 dollars; "Capex" is capital expenditure scaled by lagged assets; "R\&D" is research and development expenses scaled by lagged assets; "Sales growth" is the growth rate of sales. Column 5 (6) shows $t$-statistics for mean differences in variables between the winner and runner-up (all other) firms. $t$-statistics are based on standard errors clustered at the plant opening event level.

\begin{tabular}{|c|c|c|c|c|c|c|}
\hline \multirow{3}{*}{$\begin{array}{l}\text { Sample: } \\
\text { Statistic: } \\
\end{array}$} & \multirow{3}{*}{$\begin{array}{c}\text { (1) } \\
\text { Winner } \\
\text { Mean }\end{array}$} & \multirow{3}{*}{$\begin{array}{c}\text { (2) } \\
\text { Runner-up } \\
\text { Mean }\end{array}$} & (3) & $(4)$ & \multirow{3}{*}{$\begin{array}{c}(5) \\
(1)-(2) \\
\text { t-statistic } \\
\end{array}$} & \multirow{3}{*}{$\begin{array}{c}(6) \\
(1)-(3) \\
\text { t-statistic }\end{array}$} \\
\hline & & & \multicolumn{2}{|c|}{ All other firms } & & \\
\hline & & & Mean & $\mathrm{SD}$ & & \\
\hline$\%$ employees in winner/runner-up counties & 0.25 & 0.25 & - & - & 0.20 & - \\
\hline Book leverage & 0.33 & 0.36 & 0.33 & 0.27 & -1.99 & 0.14 \\
\hline Market leverage & 0.28 & 0.30 & 0.26 & 0.24 & -1.11 & 1.90 \\
\hline Cash holdings & 0.11 & 0.10 & 0.15 & 0.19 & 1.14 & -3.32 \\
\hline Log assets & 5.48 & 5.30 & 4.56 & 2.16 & 0.94 & 6.66 \\
\hline Tangibility & 0.32 & 0.30 & 0.28 & 0.17 & 1.75 & 4.41 \\
\hline Market-to-book & 1.83 & 1.66 & 2.14 & 2.25 & 1.41 & -2.46 \\
\hline Return on assets & 0.14 & 0.14 & 0.10 & 0.23 & -0.30 & 4.52 \\
\hline Labor intensity & 8.72 & 8.91 & 8.22 & 6.82 & -0.37 & 1.20 \\
\hline Capex & 0.27 & 0.25 & 0.35 & 0.42 & 0.56 & -3.45 \\
\hline $\mathrm{R} \& \mathrm{D}$ & 0.04 & 0.03 & 0.06 & 0.11 & 1.05 & -4.79 \\
\hline Sales growth & 0.07 & 0.08 & 0.10 & 0.32 & -0.50 & -1.85 \\
\hline Observations & 276 & 413 & 44599 & - & - & - \\
\hline
\end{tabular}


Table 3: Effect of New Manufacturing Plants on Leverage of Existing Manufacturing Firms

This table shows the effect of the opening of a manufacturing plant on the leverage of existing manufacturing firms (Compustat SIC codes 2000-3999) that operate (i.e., have plant(s) and at least 3\% of employees) in the winner county compared to those in the runner-up county for the 1975 to 2000 period. The firms that are the owners of the new plants are excluded from both of the winner and runner-up groups. "Winner" is a dummy variable equal to one if the firm operates in the winner county, and zero otherwise. "After" is a dummy variable equal to one if the firm operates in the winner or runner-up counties after the opening of a manufacturing plant, and zero otherwise. Other control variables are defined in Table 2. "NR" represents estimates that are not reported due to Census disclosure rules concerning sample size. $t$-statistics based on standard errors adjusted for sample clustering at the plant opening event level are reported below coefficient estimates in parentheses.

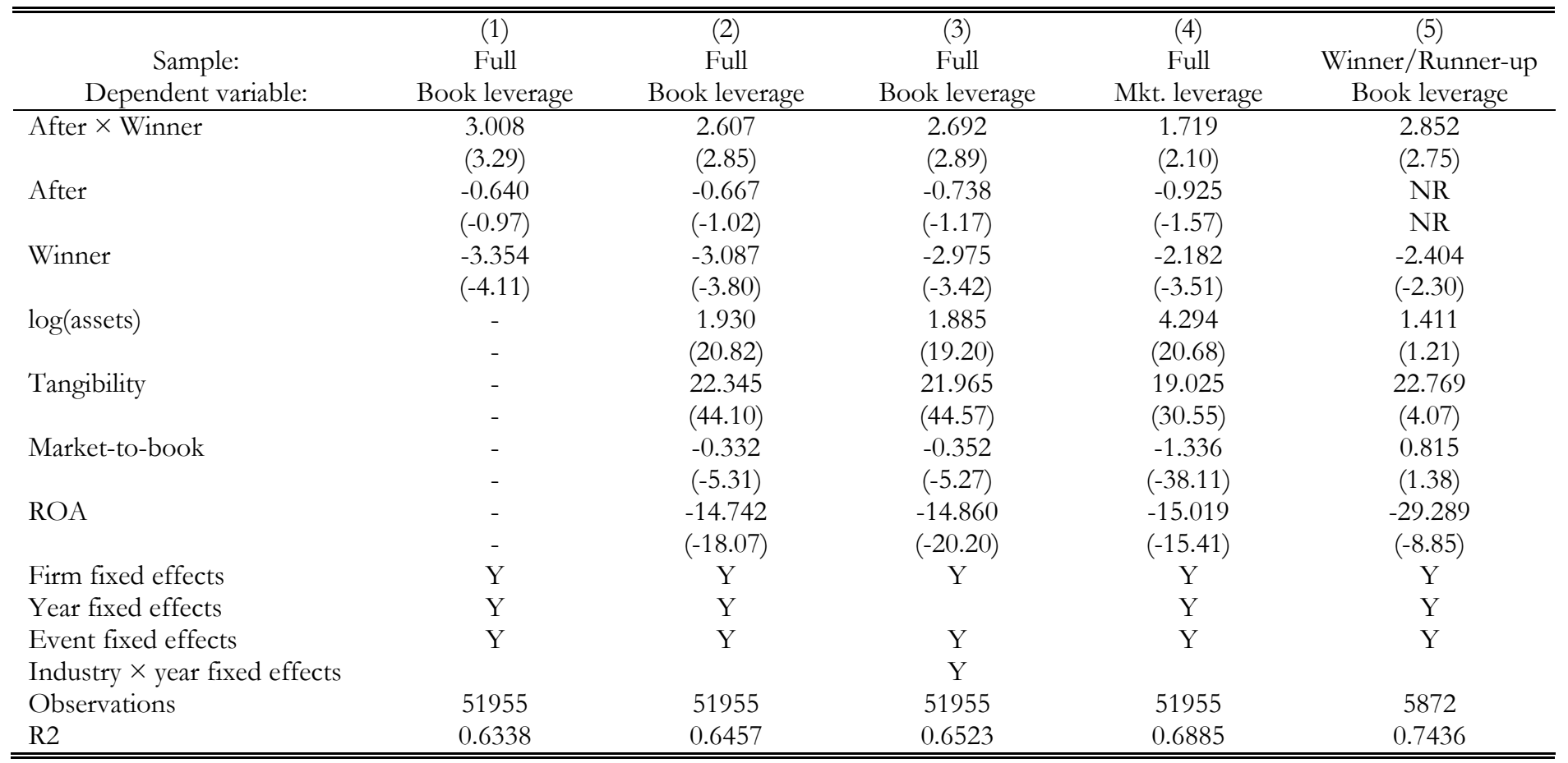




\section{Table 4: Fraction of Employees in Affected Counties and Effect of New Manufacturing Plants on Leverage}

This table estimates the effect conditional on the fraction of the existing firm's employees located in the winner or runner-up counties. "Large" ("Small") is a dummy variable equal to one if the fraction of employees in the affected (i.e., winner or runner-up) counties is larger than (smaller than or equal to) the median. $t$-statistics based on standard errors adjusted for sample clustering at the plant opening event level are reported below coefficient estimates in parentheses.

\begin{tabular}{|c|c|c|}
\hline $\begin{array}{l}\text { Fraction of employees: } \\
\text { Dependent variable: }\end{array}$ & $\begin{array}{c}(1) \\
\text { Small }\end{array}$ & $\begin{array}{l}(2) \\
\text { Large }\end{array}$ \\
\hline After $\times$ Winner & $\begin{array}{l}1.025 \\
(0.86)\end{array}$ & $\begin{array}{l}4.205 \\
(3.02)\end{array}$ \\
\hline After & $\begin{array}{l}0.623 \\
(0.64)\end{array}$ & $\begin{array}{l}-1.951 \\
(-1.62)\end{array}$ \\
\hline Winner & $\begin{array}{l}-3.296 \\
(-2.92)\end{array}$ & $\begin{array}{l}-2.752 \\
(-2.34)\end{array}$ \\
\hline Log assets & & \\
\hline Tangibility & & \\
\hline Market-to-book & & \\
\hline $\mathrm{ROA}$ & & \\
\hline Firm fixed effect & & \\
\hline Year fixed effects & & \\
\hline Event fixed effects & & \\
\hline Observations & & \\
\hline $\mathrm{R} 2$ & & \\
\hline
\end{tabular}


Table 5: Dynamic Effect of New Plants on Leverage of Existing Firms

This table shows the dynamic effect of a new manufacturing plant opening on the leverage ratios of incumbent manufacturing firms that operate plants in the winner vs. runner-up counties. The firms that are the owners of the new plants are excluded from both of the winner and runner-up groups. " $\mathrm{d}[\mathrm{t}+\mathrm{k}]$ ”, $-4 \leq \mathrm{k} \leq 4$, is a dummy variables equal to one if the firm is either in the winner or runner-up counties from four years before and after the new plant opening. " $\mathrm{d}[\mathrm{t}-1]$ " is zero by construction. Column 1 (column 2 ) shows the coefficients on " $\mathrm{d}[\mathrm{t}$ $+\mathrm{k}] \times$ Winner" (" $\mathrm{d}[\mathrm{t}+\mathrm{k}] \times$ Runner-up"), $-4 \leq \mathrm{k} \leq 4$, and column 3 shows the difference between columns 1 and 2. Other independent variables are defined in Table 2. $t$-statistics based on standard errors adjusted for sample clustering at the plant opening event level are reported below coefficient estimates in parentheses.

\begin{tabular}{|c|c|c|c|}
\hline Dependent Variable: & (1) & $\begin{array}{c}(2) \\
\text { Book leverage }\end{array}$ & (3) \\
\hline Coefficient: & Winner & Runner-up & [Winner - Runner-up] \\
\hline $\mathrm{d}[\mathrm{t}-4]$ & $\begin{array}{l}0.190 \\
(0.23)\end{array}$ & $\begin{array}{l}-0.098 \\
(-0.14)\end{array}$ & $\begin{array}{l}0.287 \\
(0.29)\end{array}$ \\
\hline $\mathrm{d}[\mathrm{t}-3]$ & $\begin{array}{l}-0.166 \\
(-0.20)\end{array}$ & $\begin{array}{l}-0.161 \\
(-0.22)\end{array}$ & $\begin{array}{r}-0.005 \\
(0.00)\end{array}$ \\
\hline$d[t-2]$ & $\begin{array}{l}-0.464 \\
(-0.74)\end{array}$ & $\begin{array}{l}0.001 \\
(0.00)\end{array}$ & $\begin{array}{c}-0.465 \\
(0.53)\end{array}$ \\
\hline$d[t-1]$ & $\begin{array}{c}0.000 \\
-\end{array}$ & $\begin{array}{c}0.000 \\
-\end{array}$ & $\begin{array}{c}0.000 \\
-\end{array}$ \\
\hline$d[t]$ & $\begin{array}{l}0.581 \\
(1.31)\end{array}$ & $\begin{array}{l}-0.475 \\
(-0.79)\end{array}$ & $\begin{array}{l}1.056 \\
(1.35)\end{array}$ \\
\hline $\mathrm{d}[\mathrm{t}+1]$ & $\begin{array}{l}2.231 \\
(3.27)\end{array}$ & $\begin{array}{l}-0.892 \\
(-1.23)\end{array}$ & $\begin{array}{l}3.123 \\
(3.19)\end{array}$ \\
\hline$d[t+2]$ & $\begin{array}{l}1.985 \\
(2.35)\end{array}$ & $\begin{array}{l}-0.620 \\
(-0.72)\end{array}$ & $\begin{array}{l}2.604 \\
(2.17)\end{array}$ \\
\hline$d[t+3]$ & $\begin{array}{l}1.618 \\
(1.88)\end{array}$ & $\begin{array}{l}-0.705 \\
(-0.71)\end{array}$ & $\begin{array}{l}2.323 \\
(1.66)\end{array}$ \\
\hline$d[t+4]$ & $\begin{array}{l}2.928 \\
(2.72)\end{array}$ & $\begin{array}{l}-0.977 \\
(-0.99)\end{array}$ & $\begin{array}{l}3.905 \\
(2.36)\end{array}$ \\
\hline $\log$ (assets) & & & \\
\hline Tangibility & & & \\
\hline Market-to-book & & & \\
\hline ROA & & & \\
\hline Firm fixed effect & & & \\
\hline Year fixed effects & & & \\
\hline Event fixed effects & & & \\
\hline Observations & & & \\
\hline R2 & & & \\
\hline
\end{tabular}




\section{Table 6: Economic Significance of Determinants of Leverage}

This table compares the economic significance of the determinants of corporate leverage based on the coefficient estimates in Table 5. For the first four determinants, columns "Std. Dev." and "Effect of typical change on leverage" show the standard deviation of the variables and the change in leverage ratio in response to a change in each of the determinants by one standard deviation, respectively. For "Plant opening (2 or 4 years)," the column "Effect of typical change on leverage" shows the change in leverage ratio in response to the opening of a typical plant in the sample, two or four years after the event.

\begin{tabular}{lcc}
\hline \hline \multicolumn{1}{c}{ Determinant } & Std. Dev. & $\begin{array}{c}\text { Effect of typical change } \\
\text { on leverage }\end{array}$ \\
\hline Log assets & 2.16 & $4.17 \%$ \\
Tangibility & 0.17 & $3.82 \%$ \\
Market-to-book & 2.25 & $-0.75 \%$ \\
Return on assets & 0.23 & $-3.38 \%$ \\
Plant opening (2 year) & - & $2.60 \%$ \\
Plant opening (4 year) & - & $3.90 \%$ \\
\hline \hline
\end{tabular}


Table 7: Labor Market Size and Displaced Workers' Wage Loss

This table presents wage patterns of displaced workers due to plant closures using the LBD and LEHD data from the US Census Bureau. "DS" is a dummy variable equal to one for workers who are displaced in mass layoff. Column 1 shows the dynamics of wages from three years before to four years after job displacement. Columns 2 and 3 interact the event time dummies with measures of labor market size (the log numbers of plants and workers in a given SIC2-county cell, respectively). $t$-statistics based on standard errors adjusted for sample clustering at the SIC2-county level are reported below coefficient estimates in parentheses.

\begin{tabular}{|c|c|c|c|}
\hline $\begin{array}{l}\text { Market size measure: } \\
\text { Dependent variable: }\end{array}$ & $\begin{array}{l}(1) \\
-\end{array}$ & $\begin{array}{c}(2) \\
\text { \# Plants } \\
\log (\text { wage })\end{array}$ & $\begin{array}{c}(3) \\
\text { \# Workers }\end{array}$ \\
\hline $\mathrm{d}[\mathrm{t}-3] \times \mathrm{DS}$ & $\begin{array}{l}-0.009 \\
(-1.20)\end{array}$ & $\begin{array}{l}-0.011 \\
(-0.54)\end{array}$ & $\begin{array}{l}-0.012 \\
(-0.32)\end{array}$ \\
\hline $\mathrm{d}[\mathrm{t}-2] \times \mathrm{DS}$ & $\begin{array}{l}-0.012 \\
(-1.25)\end{array}$ & $\begin{array}{l}-0.008 \\
(-0.34)\end{array}$ & $\begin{array}{l}-0.010 \\
(-0.21)\end{array}$ \\
\hline $\mathrm{d}[\mathrm{t}-1] \times \mathrm{DS}$ & $\begin{array}{l}-0.016 \\
(-1.44)\end{array}$ & $\begin{array}{l}-0.007 \\
(-0.29)\end{array}$ & $\begin{array}{l}-0.006 \\
(-0.10)\end{array}$ \\
\hline $\mathrm{d}[\mathrm{t}] \times \mathrm{DS}$ & $\begin{array}{c}-0.426 \\
(-16.90)\end{array}$ & $\begin{array}{l}-0.478 \\
(-7.12)\end{array}$ & $\begin{array}{l}-0.754 \\
(-7.99)\end{array}$ \\
\hline $\mathrm{d}[\mathrm{t}+1] \times \mathrm{DS}$ & $\begin{array}{c}-0.805 \\
(-16.74)\end{array}$ & $\begin{array}{l}-1.014 \\
(-8.74)\end{array}$ & $\begin{array}{l}-1.018 \\
(-4.92)\end{array}$ \\
\hline $\mathrm{d}[\mathrm{t}+2] \times \mathrm{DS}$ & $\begin{array}{c}-0.392 \\
(-11.40)\end{array}$ & $\begin{array}{l}-0.579 \\
(-6.69)\end{array}$ & $\begin{array}{l}-0.530 \\
(-3.45)\end{array}$ \\
\hline $\mathrm{d}[\mathrm{t}+3] \times \mathrm{DS}$ & $\begin{array}{l}-0.315 \\
(-9.87)\end{array}$ & $\begin{array}{l}-0.454 \\
(-5.94)\end{array}$ & $\begin{array}{l}-0.470 \\
(-3.21)\end{array}$ \\
\hline $\mathrm{d}[\mathrm{t}+4] \times \mathrm{DS}$ & $\begin{array}{l}-0.275 \\
(-8.33)\end{array}$ & $\begin{array}{l}-0.442 \\
(-5.09)\end{array}$ & $\begin{array}{l}-0.420 \\
(-2.79)\end{array}$ \\
\hline $\mathrm{d}[\mathrm{t}-3] \times \mathrm{DS} \times$ Market Size & $\begin{array}{l}- \\
-\end{array}$ & $\begin{array}{l}0.001 \\
(0.12)\end{array}$ & $\begin{array}{l}0.000 \\
(0.09)\end{array}$ \\
\hline $\mathrm{d}[\mathrm{t}-2] \times \mathrm{DS} \times$ Market Size & - & $\begin{array}{l}-0.001 \\
(-0.16)\end{array}$ & $\begin{array}{c}0.000 \\
(-0.03)\end{array}$ \\
\hline $\mathrm{d}[\mathrm{t}-1] \times \mathrm{DS} \times$ Market Size & $\begin{array}{l}- \\
-\end{array}$ & $\begin{array}{l}-0.003 \\
(-0.35)\end{array}$ & $\begin{array}{l}-0.002 \\
(-0.17)\end{array}$ \\
\hline $\mathrm{d}[\mathrm{t}] \times \mathrm{DS} \times$ Market Size & - & $\begin{array}{l}0.015 \\
(0.80)\end{array}$ & $\begin{array}{l}0.045 \\
(3.31)\end{array}$ \\
\hline $\mathrm{d}[\mathrm{t}+1] \times \mathrm{DS} \times$ Market Size & $\begin{array}{l}- \\
-\end{array}$ & $\begin{array}{l}0.063 \\
(1.86)\end{array}$ & $\begin{array}{l}0.029 \\
(0.92)\end{array}$ \\
\hline $\mathrm{d}[\mathrm{t}+2] \times \mathrm{DS} \times$ Market Size & $\begin{array}{l}- \\
-\end{array}$ & $\begin{array}{l}0.056 \\
(2.19)\end{array}$ & $\begin{array}{l}0.019 \\
(0.80)\end{array}$ \\
\hline $\mathrm{d}[\mathrm{t}+3] \times \mathrm{DS} \times$ Market Size & $\begin{array}{l}- \\
-\end{array}$ & $\begin{array}{l}0.041 \\
(1.73)\end{array}$ & $\begin{array}{l}0.021 \\
(0.96)\end{array}$ \\
\hline $\mathrm{d}[\mathrm{t}+4] \times \mathrm{DS} \times$ Market Size & $\begin{array}{l}- \\
-\end{array}$ & $\begin{array}{l}0.050 \\
(1.87)\end{array}$ & $\begin{array}{l}0.020 \\
(0.89)\end{array}$ \\
\hline Controls for $\mathrm{d}[\mathrm{t}-3]$ to $\mathrm{d}[\mathrm{t}+4]$ & Y & $\mathrm{Y}$ & $\mathrm{Y}$ \\
\hline Year fixed effects & Y & Y & Y \\
\hline Individual fixed effects & $\mathrm{Y}$ & $\mathrm{Y}$ & $\mathrm{Y}$ \\
\hline Time-varying controls & Y & $\mathrm{Y}$ & $\mathrm{Y}$ \\
\hline Observations & 173249 & 173249 & 173249 \\
\hline $\mathrm{R} 2$ & 0.6410 & 0.6413 & 0.6412 \\
\hline
\end{tabular}


Table 8: Labor Market Size vs. Other Mechanisms of Agglomeration Spillovers

This table shows heterogeneous effects of plant openings on the leverage ratios of existing manufacturing firms. Columns 1 and 2 show the effect conditional on whether the new and existing plants are in the same two-digit SIC industry. Columns 3 and 4 show the effect conditional on the frequency of worker flows between the two-digit SIC manufacturing industries of the new and existing plants, measured using the Census LEHD data. Columns 5 and 6 show the effect conditional on whether the two-digit SIC industries of the new and existing plants buy (input) or sell (output) goods with each other. Columns 7 and 8 show the effect conditional on whether the two-digit SIC industries of the new and existing plants cite patents of each other. $t$-statistics based on standard errors adjusted for sample clustering at the plant opening event level are reported below coefficient estimates in parentheses.

\begin{tabular}{|c|c|c|c|c|c|c|c|c|}
\hline Group: & $\begin{array}{c}\text { (1) } \\
\text { Same } \\
\text { industry }\end{array}$ & $\begin{array}{c}\text { (2) } \\
\text { Diff } \\
\text { industry }\end{array}$ & $\begin{array}{c}\text { (3) } \\
\text { High labor } \\
\text { flow }\end{array}$ & $\begin{array}{c}\text { (4) } \\
\text { Low labor } \\
\text { flow }\end{array}$ & $\begin{array}{c}\text { (5) } \\
\text { High IO }\end{array}$ & $\begin{array}{c}\text { (6) } \\
\text { Low IO }\end{array}$ & $\begin{array}{c}\text { (7) } \\
\text { High Citation }\end{array}$ & $\begin{array}{c}\text { (8) } \\
\text { Low Citation }\end{array}$ \\
\hline Dependent variable: & \multicolumn{8}{|c|}{ Book leverage } \\
\hline After $\times$ Winner & $\begin{array}{l}5.681 \\
(2.74)\end{array}$ & $\begin{array}{l}1.344 \\
(1.24)\end{array}$ & $\begin{array}{l}6.616 \\
(2.88) \\
\end{array}$ & $\begin{array}{l}0.881 \\
(0.82) \\
\end{array}$ & $\begin{array}{l}0.679 \\
(0.40) \\
\end{array}$ & $\begin{array}{l}3.436 \\
(3.14)\end{array}$ & $\begin{array}{l}2.094 \\
(1.25)\end{array}$ & $\begin{array}{l}2.953 \\
(2.90)\end{array}$ \\
\hline Firm-level controls & \multicolumn{2}{|c|}{$\mathrm{Y}$} & \multicolumn{2}{|c|}{$\mathrm{Y}$} & \multicolumn{2}{|c|}{$\mathrm{Y}$} & \multicolumn{2}{|c|}{$\mathrm{Y}$} \\
\hline Firm fixed effect & \multicolumn{2}{|c|}{ Y } & \multicolumn{2}{|c|}{ Y } & \multicolumn{2}{|c|}{ Y } & \multicolumn{2}{|c|}{ Y } \\
\hline Year fixed effects & \multicolumn{2}{|c|}{$\mathrm{Y}$} & \multicolumn{2}{|c|}{$\mathrm{Y}$} & \multicolumn{2}{|c|}{$\mathrm{Y}$} & \multicolumn{2}{|c|}{$\mathrm{Y}$} \\
\hline Event fixed effects & \multicolumn{2}{|c|}{$\mathrm{Y}$} & \multicolumn{2}{|c|}{ Y } & \multicolumn{2}{|c|}{$\mathrm{Y}$} & \multicolumn{2}{|c|}{$\mathrm{Y}$} \\
\hline Observations & \multicolumn{2}{|c|}{51955} & \multicolumn{2}{|c|}{51955} & \multicolumn{2}{|c|}{51955} & \multicolumn{2}{|c|}{51955} \\
\hline $\mathrm{R} 2$ & \multicolumn{2}{|c|}{0.6461} & \multicolumn{2}{|c|}{0.6461} & \multicolumn{2}{|c|}{0.6461} & \multicolumn{2}{|c|}{0.6461} \\
\hline
\end{tabular}




\section{Table 9: Marginal Tax Benefits of Debt and Leverage Changes}

This table examines whether the firm's incremental benefits due to levering up affect its capital structure choices in response to the opening of a new manufacturing plant by estimating the effect conditional on the corporate marginal income tax rate. Column 1 ("Low") shows the effect of a plant opening for firms with marginal tax rates (MTRs), computed using a simulation procedure in Graham (2000), less than the statutory rate, and column 2 ("High") for firms with MTRs that are equal to the statutory rate. Other independent variables are defined in Table 2. $t$-statistics based on standard errors adjusted for sample clustering at the plant opening event level are reported below coefficient estimates in parentheses.

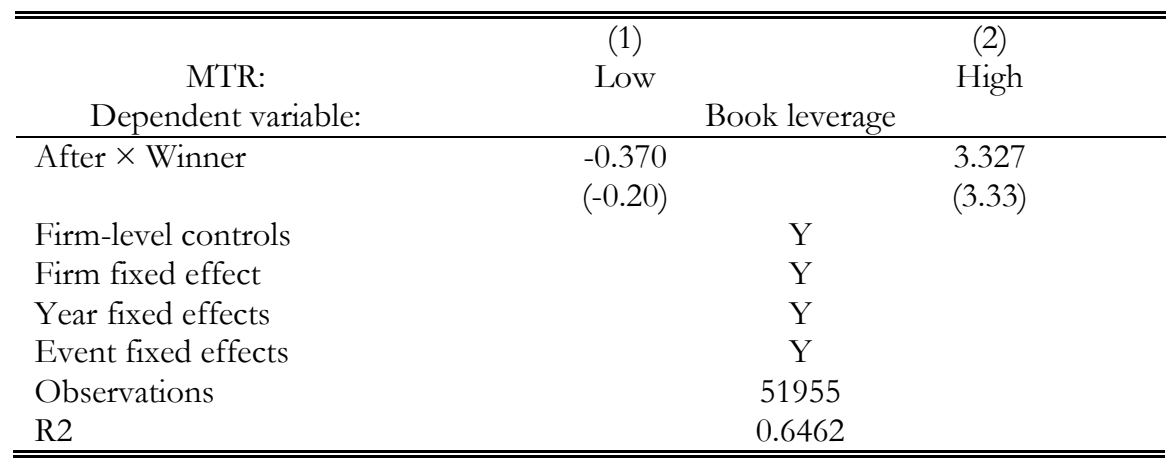

\section{Table 10: Labor Market Size, Wages, and Labor Productivity}

This table shows the effect of a new manufacturing plant opening on wages and productivity of workers at existing plants in the "winner" vs. "runner-up" counties. The plant observations are from the Census of Manufacturers and Annual Survey of Manufacturers from the US Census Bureau. All dependent variables are in log scale. "Average wage" is computed as total wages divided by the number of total employees; "Wage per hour" is total production worker wages divided by total production labor hours; "Labor productivity" is defined as output divided by total labor hours; $t$-statistics based on standard errors adjusted for sample clustering at the plant opening event level are reported below coefficient estimates in parentheses.

\begin{tabular}{lccc}
\hline \multicolumn{1}{c}{$\begin{array}{c}\text { Sample: } \\
\text { Dependent variable: }\end{array}$} & $(1)$ & $(2)$ & $(3)$ \\
& & Plants & \\
& Average wage & Wage per worker & Labor productivity \\
\hline After $\times$ Winner & -0.004 & 0.006 & 0.031 \\
After & $(-0.35)$ & $(0.61)$ & $(1.98)$ \\
& 0.009 & 0.005 & -0.022 \\
Winner & $(1.56)$ & $(0.67)$ & $(-2.56)$ \\
& 0.001 & -0.005 & -0.019 \\
$\log ($ plant per firm) & $(0.24)$ & $(-0.73)$ & $(-1.46)$ \\
& 0.004 & 0.006 & 0.010 \\
$\log ($ plant per segment) & $(28.01)$ & $(19.17)$ & $(30.12)$ \\
& -0.002 & 0.004 & 0.014 \\
Plant fixed effects & $(-14.78)$ & $(22.97)$ & $(36.15)$ \\
Industry $\times$ Year fixed effects & $\mathrm{Y}$ & $\mathrm{Y}$ & $\mathrm{Y}$ \\
Event fixed effect & $\mathrm{Y}$ & $\mathrm{Y}$ & $\mathrm{Y}$ \\
Observations & $\mathrm{Y}$ & $\mathrm{Y}$ & $\mathrm{Y}$ \\
R2 & 991379 & 991379 & 991379 \\
\hline \hline
\end{tabular}




\section{Online Appendices}

\section{Online Appendix A - External Validity: Analysis of Panel Data}

\section{A.1. Empirical Approach and Sample Construction}

The empirical analysis in the main text provides the first evidence on the relation between labor market size and firm capital structure decisions. However, the external validity of the results is not warranted given that the analysis is based on a selected sample of large plant opening events. In this appendix, I aim to gauge whether the relationship holds in a more general setting using a broad panel of Compustat firms. To this end, I first construct a measure of local labor market size following a similar approach to the previous analysis. Specifically, for each two-digit SIC industry and county cell, I measure its labor market size using the number of potential employers (i.e., other plants) based on the LBD data (see Section 5.3). ${ }^{1}$ Then, I compute a firm-level measure of labor market size as the log of one plus the value-weighted average of the number of other manufacturing plants in the industry and county in which the firm operates (e.g., Tate and Yang, 2015):

Labor market size $_{i t}=\log \left(1+\sum_{j} \sum_{c} w_{i j c t} \times\right.$ num. of plants $\left.s_{i j c t}\right)$,

where Labor market size $_{\mathrm{it}}$ is the measure of labor market size of firm $\mathrm{i}$ in year $\mathrm{t}, \mathrm{w}_{\mathrm{ijct}}$ is the fraction of firm i's workers, and num. of plants $\mathrm{ijct}_{\mathrm{j}}$ is the number of other manufacturing plants located in industry $j$, county c, and year t. I use the log of the measure in empirical analysis given that the raw measure is highly right-skewed.

To avoid biases in the estimate due to firm-specific permanent component in leverage ratios as well as the measure of labor market size, I estimate the following leverage equation with firm and year fixed effects (e.g., Lemmon, Roberts, and Zender, 2008):

Leverage $_{i t}=\alpha_{i}+\alpha_{t}+\beta_{1}$ Labor market size $i t-1+\gamma^{\prime} X_{i t}+\varepsilon_{i t}$,

where $\alpha_{i}$ is firm fixed effects, $\alpha_{t}$ is year fixed effects, Leverage $e_{i t}$ is leverage ratio, Labor market size $_{\mathrm{it}-1}$ is a lagged firm-level measure of market size computed in equation (A1), $\mathrm{X}_{\mathrm{it}}$ is a set of

${ }^{1}$ This approach is also consistent with the asset redeployability literature which measures the size (or thickness) of asset markets using the number of potential buyers (e.g., Benmelech, 2009; Gavazza, 2011). Another potential proxy for local labor market size is the number of workers in a given industry and county. However, the number of workers can be correlated with the degree of competition for similar jobs, and thus it is not an ideal proxy. Consistent with this argument, Section 5.3 shows that the number of workers is not significantly associated with the magnitude of wage loss after a job loss. 
firm-level control variables described in equation (5), and $\varepsilon_{\mathrm{it}}$ is the residual for firm $\mathrm{i}$ in year $\mathrm{t}$. Standard errors are adjusted for sample clustering at the firm level. Given the firm fixed effects included, my identification relies on within-firm variation in labor market size and leverage. I use book leverage as the dependent variable for my main analysis but results are qualitatively similar for market leverage (unreported).

Consistent with the sample construction in the main text, I focus on firm-year observations in the manufacturing industries from Compustat (SIC codes 2000-3999). Further, I obtain plant-level data on location and industry classification from the LBD. I link these plant observations to firm observations from Compustat using a bridge file created by the Census Bureau. Given that the LBD data are available from 1976 to 2009 and I lag the measure of market size computed using the LBD by one year relative to firm-level variables, the sample period is from 1977 to 2010. Finally, following the approach in Section 5.3, I focus on firm-year observations with a measure of labor market size larger than its median. The resulting sample includes 22,959 firm-year observations from 1977 to 2010.

Online Appendix Table 7 shows descriptive statistics on the firm-year observations used in the panel analysis. Notably, a typical firm in the sample has approximately 63 (= $\exp (4.14))$ other plants in its local labor markets. Statistics for leverage ratios and financial control variables are generally similar with corresponding values reported in Table 2.

\section{A.2. Empirical Results}

Online Appendix Table 8 presents the estimation results for the model in equation (A2). The specification in column 1 includes firm and year fixed effects but excludes other financial controls variables. The coefficient on "Market size (SIC2-county)" is 1.38 and statistically significant at the $1 \%$ level, suggesting that the size of labor markets is positively associated with firm leverage ratios. Column 2 further includes the financial control variables to the baseline regression and shows a qualitatively similar result. Column 3 includes "Market size (all mfg-county)" as an additional control which proxies for general population of manufacturing plants in a given county. Although the inclusion of this variable marginally increases the effect of labor market size, the result is qualitatively similar to that in column 2. In terms of economic magnitude, the coefficient estimate suggest that a one standard 
deviation increase in market size leads to a $1.44(=1.34 \times 1.08)$ percentage point increase in leverage ratio. Column 4 uses the log number of workers as an alternative (but less preferred) measure of market size, and shows a somewhat less significant relation between market size and firm leverage $(t$-stat $=1.67)$. A one standard deviation increase in the log number of workers in the SIC2-county cell leads to a $1.06(=0.79 \times 1.35)$ percentage point increase in leverage.

Overall, the results based on a large panel of firms are consistent with the results based on plant opening events, showing that firms operating in a large labor market use more debt compared to equity. Moreover, if variation in the firm-level measure of labor market size is exogenous after controlling for firm and year fixed effects and the financial characteristics, these estimates could have a causal interpretation (which is plausible given that the measure is partly driven by the opening and closing of plants owned by other firms in a given industry and county). However, I interpret these results with caution given the potential endogeneity of firm location.

\section{Online Appendix B - Discussion of Value Impact of Leverage Increase}

Table 5 shows that an average manufacturing plant opening in the sample leads existing manufacturing firms in the winner county to increase their debt-to-capital ratio by 3.9 percentage points in four years after the opening. In this appendix, I discuss the value implications of this leverage increase. First, the measure of financial leverage that I use (i.e., debt-to-capital ratio) is different from the debt-to-book assets ratio, a popular measure of leverage. $^{2}$ Over the 1980-1995 period, the mean debt-to-capital and debt-to-book assets ratios for Compustat manufacturing firms are 33.0\% and 23.3\%, respectively. Applying this relative magnitude, the 3.9 percentage point change in the debt-to-capital ratio I find can be translated to a 2.8 percentage point change in the debt-to-assets ratio. Hence, I use the 2.8 percentage point increase as the effect of the plant opening to be consistent with magnitudes discussed in existing research on capital structure (e.g., Almeida and Philippon, 2007).

\footnotetext{
${ }^{2}$ See Welch (2011) for advantages of using the debt-to-capital instead of the debt-to-assets ratio in capital structure research.
} 
Now, I attempt to quantify the economic magnitude of the effect of additional debt usage on firm value. I focus on interest tax deduction as the source of benefits. The marginal corporate tax rate adjusted for personal tax penalty of debt is assumed to be $16 \%$ for an average firm (Graham, 2000; Almeida and Philippon, 2007). Then, a 2.8 percentage point perpetual increase in leverage ratio implies an incremental gross tax benefit equal to $0.45 \%$ $(=16 \% \times 2.8 \%)$ of book assets. However, this estimate does not account for an additional cost of financial distress due to increased leverage, and so should be interpreted as an upper bound for the net benefit of the leverage increase. If I apply the recent finding that net benefits of debt are approximately one-third of gross benefits of leverage (e.g., van Binsbergen et al., 2010), the net benefits due to the incremental leverage would be about $0.15 \%$ of book assets. Given that there are on average about seven public firms in the winner county with an average book assets value of $\$ 2.18$ billion, this estimate implies an aggregate value impact of the leverage increase ranging from $\$ 22.8$ (net) to $\$ 68.4$ million (gross). These values are $0.9 \%$ to $2.6 \%$ of the aggregate manufacturing output in the average winner county ( $\$ 2.58$ billion).

While this magnitude of incremental firm value may appear to be large at first glance given the local nature of the shocks, it is reasonable in the following sense. First, workers in the winner or runner-up county account for $25 \%$ of the total workforce of parent firms on average, implying that the large plant opening would significantly increase the size of labor markets that the parent firms face. Second, the estimate represents a "general equilibrium" effect of an expansion in local labor market size triggered by the introduction of a large plant. As GHM (2010) document using a similar sample, the winner county experiences a significant increase in market size (proxied by the number of manufacturing plants) even several years after the plant opening. Thus, the magnitude should incorporate the effect of the expected future (as well as realized) increase in labor market size.

\section{References}

Almeida, Heitor and Thomas Philippon, 2007, The Risk-Adjusted Cost of Financial Distress, Journal of Finance 62, 2557-2586.

van Binsbergen, Jules H., John R. Graham, and Jie Yang, 2010, The Cost of Debt, Journal of Finance 65, 2089-2136. 
Benmelech, Efraim, 2009, Asset Salability and Debt Maturity: Evidence from Nineteenth Century American Railroads, Review of Financial Studies 22, 1545-1583.

Gavazza, Alessandro, 2011, The Role of Trading Frictions in Real Asset Markets, American Economic Review 101, 1106-1143.

Graham, John R., 2000, How Big are the Tax Benefits of Debt?, Journal of Finance 55, 1901-1941.

Greenstone, Michael, Richard Hornbeck, and Enrico Moretti, 2010, Identifying Agglomeration Spillovers: Evidence from Winners and Losers of Large Plant Openings, Journal of Political Economy 118, 536-598.

Lemmon, Michael L., Michael R. Roberts, and Jaime F. Zender, 2008, Back to the Beginning: Persistence and the Cross-section of Corporate Capital Structure, Journal of Finance 63, 1575-1608.

Tate, Geoffrey A. and Liu Yang, 2015, The Bright Side of Corporate Diversification: Evidence from Internal Labor Markets, Review of Financial Studies 28, 2203-2249.

Welch, Ivo, 2011, Two Common Problems in Capital Structure Research: The FinancialDebt-To-Asset Ratio and Issuing Activity Versus Leverage Changes, International Review of Finance 11, 1-17. 


\section{Online Appendix Tables}

\section{Table 1: Plant Characteristics for Winner and Runner-up Counties}

This table shows means of plant-level characteristics for those in the winner and runner-up counties (measured one year prior to the large plant opening) as well as plants in all other US counties. Column 4 (column 5) shows $t$-statistics for the difference in each variable between the winner and runner-up (all other US) counties. The sample is restricted to plants that had existed for the seven consecutive years prior to the opening of the new manufacturing plant, but excludes the new plant itself and any plants owned by the opening firm. "Output" is total value of shipments and a measure of sales from plants in thousand dollars; "\% change, over last 5 years" is the annualized growth rate of plant output over the five years before the plant opening; "Total employees" is the number of total employees; "Total hours" is the number of production and non-production worker hours; "Capital" is the sum of real net stock of equipment and structures in thousand dollars, constructed using a perpetual inventory formula.

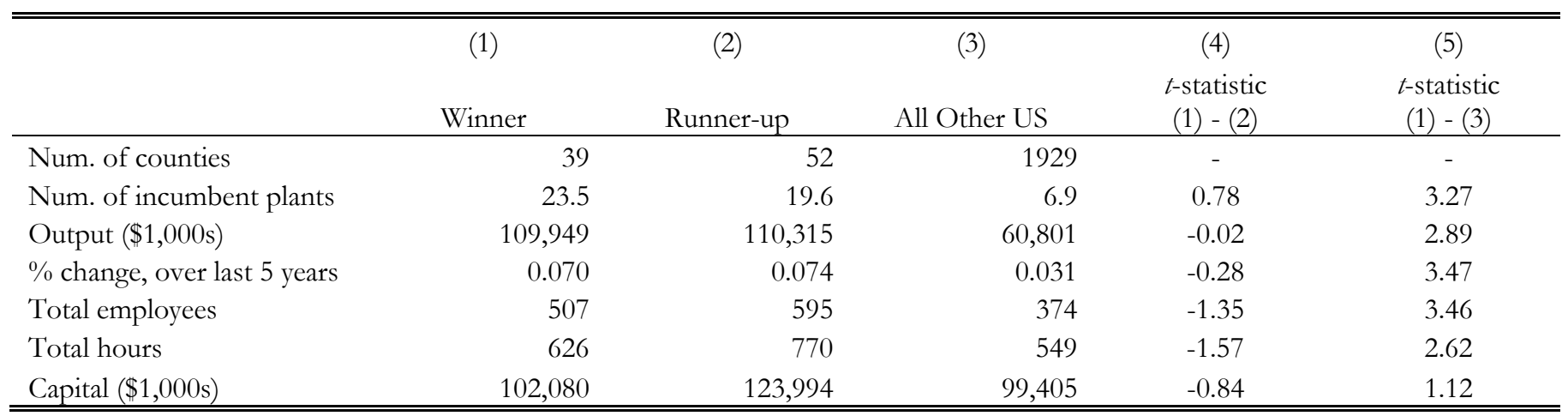




\section{Table 2: Collateral Channels - Property Values}

This table examines the robustness of the main results to an alternative explanation concerning property collateral values. It includes an additional control variable to capture the effect of property values which are hand-collected from the Survey of Government, Volume 2 Taxable Property Values and Assessment-Sales Price Ratios (1977, 1982, 1987, and 1992). $t$-statistics based on standard errors adjusted for sample clustering at the plant opening event level are reported below coefficient estimates in parentheses.

\begin{tabular}{|c|c|c|}
\hline & (1) & (2) \\
\hline Dependent variable: & \multicolumn{2}{|c|}{ Book leverage } \\
\hline \multirow[t]{2}{*}{ After $\times$ Winner } & 2.998 & 2.945 \\
\hline & $(2.46)$ & $(2.46)$ \\
\hline \multirow[t]{2}{*}{ After } & -1.093 & -1.044 \\
\hline & $(-1.15)$ & $(-1.09)$ \\
\hline \multirow[t]{2}{*}{ Winner } & -1.667 & -1.482 \\
\hline & $(-1.75)$ & $(-1.51)$ \\
\hline \multirow[t]{2}{*}{$\log$ (assets) } & 0.620 & 0.623 \\
\hline & $(0.30)$ & $(0.30)$ \\
\hline \multirow[t]{2}{*}{ Tangibility } & 9.450 & 9.848 \\
\hline & $(0.95)$ & $(0.98)$ \\
\hline \multirow[t]{2}{*}{ Market-to-book } & -0.442 & -0.425 \\
\hline & $(-0.62)$ & $(-0.59)$ \\
\hline \multirow[t]{2}{*}{$\mathrm{ROA}$} & -31.230 & -31.279 \\
\hline & $(-5.67)$ & $(-5.68)$ \\
\hline \multirow[t]{2}{*}{ Log property values } & - & 0.742 \\
\hline & - & $(1.40)$ \\
\hline Firm fixed effects & $\mathrm{Y}$ & $\mathrm{Y}$ \\
\hline Year fixed effects & $\mathrm{Y}$ & $\mathrm{Y}$ \\
\hline Event fixed effects & Y & $\mathrm{Y}$ \\
\hline Observations & 3735 & 3735 \\
\hline $\mathrm{R} 2$ & 0.7998 & 0.8000 \\
\hline
\end{tabular}

Table 3: Uneven Geographical Distribution of Winners and Runners-up

This table examines the robustness of the main results to the uneven distribution of the winner and runner-up counties among geographic regions. It estimates the effect of manufacturing plant opening focusing on events in which both of the winner and runner-up counties are in the same Census region (i.e., Northeast, Midwest, South, or West). $t$-statistics based on standard errors adjusted for sample clustering at the plant opening event level are reported below coefficient estimates in parentheses.

\begin{tabular}{lccc}
\hline \hline & $(1)$ & $(2)$ \\
$\begin{array}{l}\text { Dependent variable: } \\
\text { Same Census region: }\end{array}$ & Different & & \\
\hline After $\times$ Winner & 2.601 & & Same \\
& $(2.81)$ & & $(1.47)$ \\
Firm-level controls & & Y & \\
Firm fixed effect & & Y & \\
Year fixed effects & & Y & \\
Event fixed effects & & Y & \\
Observations & & 51955 & \\
R2 & & 0.6457 & \\
\hline \hline
\end{tabular}




\section{Table 4: Bargaining Power with Employees}

This table examines the robustness of the main results to alternative explanations concerning bargaining power with labor. Columns 1 and 2 estimate the effect of a plant opening separately for firms in industries with unionization rates higher than or equal to, or lower than $25 \%$. Columns 3 and 4 estimate the effect of a plant opening separately for firms with return on assets (ROA) that is higher than or equal to, or lower than the median. $t$-statistics based on standard errors adjusted for sample clustering at the plant opening event level are reported below coefficient estimates in parentheses.

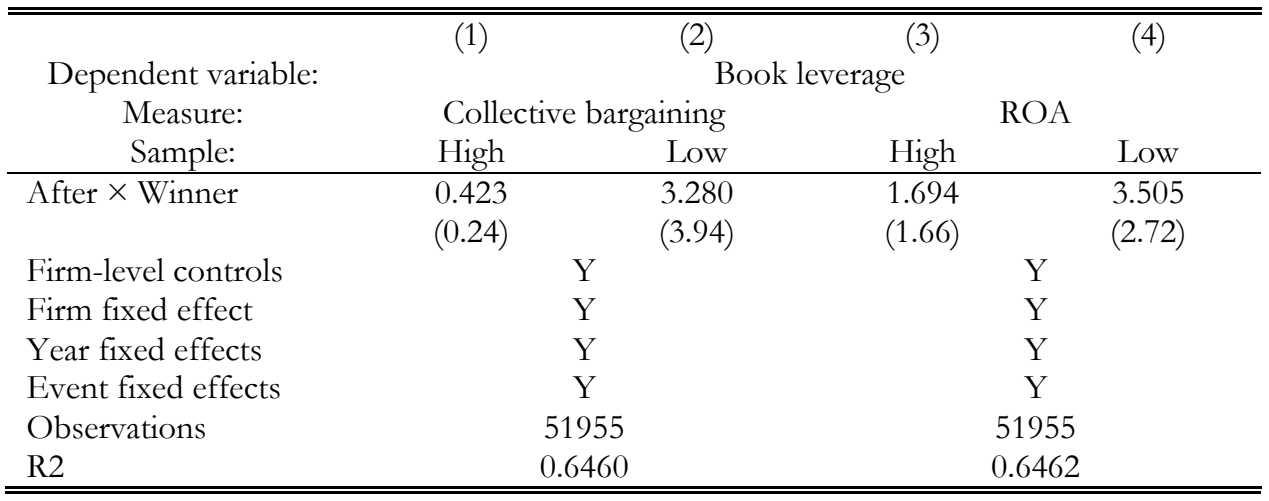

\section{Table 5: Manufacturing vs. Non-manufacturing Establishments Openings}

This table examines the robustness of the main results to alternative explanations concerning countywide shocks. It shows the effect of a large manufacturing plant opening on the leverage ratios of existing nonmanufacturing firms (column 1) and vice versa (column 2). $t$-statistics based on standard errors adjusted for sample clustering at the plant opening event level are reported below coefficient estimates in parentheses.

\begin{tabular}{|c|c|c|}
\hline \multirow{4}{*}{$\begin{array}{c}\text { Dependent variable: } \\
\text { New plant: } \\
\text { Existing firms: }\end{array}$} & (1) & (2) \\
\hline & \multicolumn{2}{|c|}{ Book leverage } \\
\hline & Manufacturing & Non-manufacturing \\
\hline & Non-manufacturing & Manufacturing \\
\hline \multirow[t]{2}{*}{ After $\times$ Winner } & -1.654 & -0.078 \\
\hline & $(-1.19)$ & $(-0.11)$ \\
\hline \multirow[t]{2}{*}{ After } & 1.370 & -0.350 \\
\hline & $(1.43)$ & $(-0.50)$ \\
\hline \multirow[t]{2}{*}{ Winner } & 2.092 & -0.026 \\
\hline & $(1.47)$ & $(-0.02)$ \\
\hline Firm-level controls & $\mathrm{Y}$ & $\mathrm{Y}$ \\
\hline Firm fixed effects & $\mathrm{Y}$ & Y \\
\hline Year fixed effects & $\mathrm{Y}$ & Y \\
\hline Event fixed effects & Y & Y \\
\hline Observations & 40353 & 53361 \\
\hline $\mathrm{R} 2$ & 0.7263 & 0.6440 \\
\hline
\end{tabular}




\section{Table 6: MSA-level Effect}

This table examines the robustness of the main results to the geographical definition of local labor markets by extending the definition to Metropolitan Statistical Areas (MSAs). $t$-statistics based on standard errors adjusted for sample clustering at the plant opening event level are reported below coefficient estimates in parentheses.

\begin{tabular}{lc}
\hline \hline \multicolumn{1}{c}{ Dependent variable: } & $(1)$ \\
\hline After $\times$ Winner & Book leverage \\
After & 0.833 \\
& $(1.52)$ \\
Winner & 0.242 \\
& $(0.83)$ \\
Firm-level controls & -0.803 \\
Firm fixed effects & $(-1.89)$ \\
Year fixed effects & $\mathrm{Y}$ \\
Event fixed effects & $\mathrm{Y}$ \\
Observations & $\mathrm{Y}$ \\
R2 & $\mathrm{Y}$ \\
\hline \hline
\end{tabular}




\section{Table 7: Descriptive Statistics for Panel Data Analysis}

This table shows descriptive statistics on firm-year observations in manufacturing industries (SICs from 2000 to 3999) from Compustat used in the panel data analysis for the 1977 to 2010 period. "log number of plants (workers), SIC2-county" is the log number of plants (workers) in the two-digit SIC industry and county. All other variables are defined in Table 2.

\begin{tabular}{|c|c|c|}
\hline & $(1)$ & $(2)$ \\
\hline Variable & Mean & $\mathrm{SD}$ \\
\hline Book leverage & 0.33 & 0.27 \\
\hline Market leverage & 0.25 & 0.24 \\
\hline Cash holdings & 0.13 & 0.17 \\
\hline Log assets & 4.66 & 2.09 \\
\hline Tangibility & 0.30 & 0.17 \\
\hline Market-to-book & 1.98 & 1.85 \\
\hline Return on assets & 0.11 & 0.19 \\
\hline Labor intensity & 9.32 & 36.19 \\
\hline Capex & 0.29 & 0.33 \\
\hline $\mathrm{R} \& \mathrm{D}$ & 0.05 & 0.08 \\
\hline Sales growth & 0.09 & 0.26 \\
\hline Log number of plants, SIC2-county & 4.14 & 1.08 \\
\hline Log number of workers, SIC2-county & 7.84 & 1.35 \\
\hline Observations & 22959 & - \\
\hline
\end{tabular}

Table 8: Panel Estimates for Relation between Labor Market Size and Leverage

This table shows estimation results for the panel regression of leverage ratios on a measure of the size of local labor markets, firm and year fixed effects, and firm-level control variables using firm-years in manufacturing industries (SICs from 2000 to 3999) from Compustat from 1977 to 2010. Columns 1-3 (4) use the (log) number of plants (workers) as a measure of market size. $t$-statistics based on standard errors adjusted for sample clustering at the firm level are reported below coefficient estimates in parentheses.

\begin{tabular}{|c|c|c|c|c|}
\hline Market size measure: & $\begin{array}{c}(1) \\
\text { \# Plants }\end{array}$ & $\begin{array}{c}(2) \\
\text { \# Plants }\end{array}$ & $\begin{array}{c}\text { (3) } \\
\text { \# Plants }\end{array}$ & $\begin{array}{c}\text { (4) } \\
\text { \# Workers }\end{array}$ \\
\hline Dependent variable: & \multicolumn{4}{|c|}{ Book leverage } \\
\hline \multirow[t]{2}{*}{ Market size (SIC2-county) } & 1.376 & 1.237 & 1.335 & 0.787 \\
\hline & $(2.81)$ & $(2.57)$ & $(2.28)$ & $(1.67)$ \\
\hline \multirow[t]{2}{*}{ Market size (All mfg-county) } & - & - & 0.207 & 0.200 \\
\hline & - & - & $(0.23)$ & $(0.24)$ \\
\hline \multirow[t]{2}{*}{$\log$ (assets) } & - & 0.440 & 0.444 & 0.469 \\
\hline & - & $(0.77)$ & $(0.78)$ & $(0.84)$ \\
\hline \multirow[t]{2}{*}{ Tangibility } & - & 21.933 & 21.912 & 21.707 \\
\hline & - & $(6.38)$ & $(6.37)$ & $(6.28)$ \\
\hline \multirow[t]{2}{*}{ Market-to-book } & - & -0.555 & -0.555 & -0.558 \\
\hline & - & $(-3.75)$ & $(-3.75)$ & $(-3.77)$ \\
\hline \multirow[t]{2}{*}{ ROA } & - & -16.438 & -16.445 & -16.504 \\
\hline & - & $(-9.67)$ & $(-9.66)$ & $(-9.70)$ \\
\hline Firm fixed effects & $\mathrm{Y}$ & $\mathrm{Y}$ & Y & $\mathrm{Y}$ \\
\hline Year fixed effects & $\mathrm{Y}$ & $\mathrm{Y}$ & $\mathrm{Y}$ & $\mathrm{Y}$ \\
\hline Observations & 22959 & 22959 & 22959 & 22959 \\
\hline R-squared & 0.6724 & 0.6839 & 0.6839 & 0.6837 \\
\hline
\end{tabular}

